\title{
Belajar Pocapan dari Ki Hadi Sugito
}

\author{
Endah Budiarti \\ Jurusan Pedalangan, Fakultas Seni Pertunjukan, Institut Seni Indonesia Yogyakarta \\ Email: endahbudiarti30@yahoo.co.id
}

\begin{abstract}
This paper discusses the application of the method of learning puppetry, especially Pocapan language (dialogue with puppet characters'). This method is produced by first examining Ki Hadi Sugito's pocapan in three plays, namely Bagong Ratu, Ujung Sengara, and Wahyu Widayat. Ki Hadi Sugito's wayang performance was chosen as a model with language considerations produced by Ki Hadi Sugito, simple and communicative. From the results of the study, a simpler text was created. This text is then used as teaching material in class. The text used as this teaching material does not mean limiting students but instead provides opportunities to be developed by students, according to their respective abilities.
\end{abstract}

Keywords: pocapan; Ki Hadi Sugito; model; method

\begin{abstract}
Abstrak
Tulisan ini membicarakan penerapan metode belajar bahasa pedalangan khususnya bahasa pocapan ('mendialogkan tokoh-tokoh wayang'). Metode ini dihasilkan dengan terlebih dahulu meneliti pocapan Ki Hadi Sugito dalam tiga lakon yaitu Bagong Ratu, Ujung Sengara, dan Wahyu Widayat. Pergelaran wayang versi Ki Hadi Sugito dipilih sebagai model dengan pertimbangan bahasa yang diproduksi Ki Hadi Sugito sederhana dan komunikatif. Dari hasil penelitian tersebut dibuatlah sebuah teks pocapan yang lebih sederhana. Teks ini kemudian digunakan sebagai bahan ajar di kelas. Teks yang digunakan sebagai bahan ajar ini tidak berarti membatasi mahasiswa tetapi justru memberi peluang untuk dikembangkan oleh mahasiswa, sesuai dengan kemampuan masing-masing.
\end{abstract}

Kata kunci: pocapan; Ki Hadi Sugito; model; metode

\section{Pendahuluan}

Zaman yang serba praktis dan pragmatis ruparupanya juga berimbas pada makin sederhananya masyarakat Jawa dalam berbahasa. Unggah-ungguh bahasa Jawa dengan segala ragamnya sudah hampir ditinggalkan. Bahkan jika dicermati orang Jawa sekarang ini kebanyakan hanya mengenal ragam ngoko dalam bahasa Jawa dan kosa kata Indonesia. Struktur bahasa Jawa mereka saat ini adalah struktur bahasa Indonesia. Artinya ketika berbicara atau menulis bahasa Jawa mereka memakai struktur bahasa Indonesia namun kata-kata yang dipakai adalah kata-kata bahasa Jawa. Mahasiswa Pedalangan termasuk menjadi bagian di dalamnya, yaitu warga masyarakat yang berada dalam situasi memudarnya beberapa tatanan masyarakat Jawa akibat dari dunia yang tanpa sekat ini. Sehingga mereka kurang menguasai bahasa Jawa yang dalam konteks seni pertunjukan wayang sama artinya 
mereka kurang menguasai bahasa pedalangan (bahasa wayang). Padahal mereka adalah calon dalang, tukang cerita. Fenomena ini kiranya memerlukan suatu jalan keluar. Yaitu bagaimana bahasa wayang yang mendapat predikat sulit dan rumit dipandang sebagai suatu yang nikmat dan memikat.

Nikmat dan memikat dua kata yang kiranya tidak terlalu salah jika dilekatkan pada gaya tuturan Ki Hadi Sugito ketika mempergelarkan wayang. Siapapun dapat dipastikan menikmatinya dan terpikat oleh kesegaran dan kesederhanaan bahasanya. Dua kata yang sebenarnya tidak mudah untuk direduksi dalam pergelaran wayang oleh setiap dalang. Namun dua kata itu mengundang untuk ditemukannya struktur bahasa Ki Hadi Sugito. Sehingga nantinya dapat dijadikan model bagi mahasiswa Pedalangan dalam belajar bahasa wayang.

Ki Hadi Sugito sebagai dalang, kiranya tidak perlu diragukan kepopulerannya, khususnya di Yogyakarta. Setelah wafat pun pertunjukannya masih dapat dinikmati oleh penggemar-penggemarnya hampir setiap malam di stasiun-stasiun radio di Yogyakarta. Kesegaran yang ditawarkan dapat dikatakan menembus ruang dan waktu. Yang diperlu dicatat di sini ialah penggemarnya tidak hanya terbatas pada masyarakat penonton namun juga dari kalangan para dalang generasi berikutnya. Udreka (2011: 22) mengatakan bahwa dalangdalang muda banyak yang mengikuti jejak Ki Hadi Sugito dalam hal caking pakeliran ('membawakan pertunjukan wayang'). Seno Nugroho (wawancara, 2015) seorang dalang muda yang sangat popular di tahun 2000-an, dalam suatu wawancara mengatakan bahwa ia sangat mengidolakan Ki Hadi Sugito. Ia belajar banyak darinya bagaimana membuat pertunjukan terasa segar dan komunikatif.

Kemampuan-kemampuan yang melekat pada diri Ki Hadi Sugito inilah yang diperlukan oleh mahasiswa Pedalangan, yang notabene adalah generasi yang hidup saat seni pertunjukan wayang kulit telah mengalami banyak pencairan, untuk menjadi seorang seniman yang diterima masyarakatnya. Masyarakat global, masyarakat tanpa sekat.

Bagaimana Ki Hadi Sugito menggunakan dan memilih ragam bahasa Jawa sehingga ia mampu mencairkan batas bahasa wayang dengan bahasa sehari-hari akan dicermati untuk kemudian dijadikan sebuah model belajar bahasa pedalangan khususnya bahasa pocapan.

\section{Konsep Ragam Bahasa}

Ragam bahasa adalah jenis kode bahasa yang penggunaannya ditentukan oleh kemampuan memilih dan memilah kata-kata bahasa Jawa secara cermat (Sasangka, 2004: 3). Selain kemampuan memilih dan memilah kata, penutur bahasa Jawa harus mengenal ciri pembeda antara ragam yang satu dan ragam yang lain serta antara jenis leksikon satu dengan jenis leksikon lain (Sasangka, 2004: 6). Suatu untaian kalimat disebut ngoko atau krama sebenarnya bergantung pada pemakaian dan pemilihan leksikon atau kata (kosa kata) di dalam kalimat itu secara tepat (Sasangka, 2004: 24).

Leksikon merupakan komponen bahasa yang memuat semua informasi tentang makna dan pemakaian kata dalam suatu bahasa (Kridalaksana, 1993: 127). Leksikon merupakan kekayaan kata yang dimiliki suatu bahasa. Berdasarkan bentuknya, Sasangkat (2004:25) membedakan leksikon bahasa Jawa menjadi enam yaitu leksikon (1) ngoko, (2) madya, (3) krama, (4) krama inggil, (5) krama andhap, (6) netral. Jika dilihat dari segi makna atau dari sudut pragmatis dan/atau semantik, Sasangka (2004: 50) membedakan leksikon bahasa Jawa menjadi tiga yaitu (1) halus, (2) biasa, dan (3) kasar. Pembagian itu berdasarkan asumsi bahwa pengertian kasar-biasa-halusnya suatu kata atau leksikon sebenarnya berkaitan dengan nilai rasa. Leksikon halus merupakan leksikon yang mencerminkan kesantunan.

Selain leksikon yang telah disebutkan, masih ada jenis leksikon lain yaitu leksikon yang pemakaiannya hanya terbatas pada ragam susastra (literer), leksikon itu adalah leksikon kawi. Sampai saat ini leksikon kawi masih tetap digunakan tetapi hanya terbatas pada ragam susastra, misalnya digunakan dalam pewayangan, tembang macapat, geguritan, pidato dalam resepsi pernikahan atau khitanan (Sasangka, 2004: 55)

Sasangka (2004: 95-115) membedakan ragam bahasa Jawa menjadi dua bentuk yaitu ragam ngoko dan ragam krama. Yang dimaksud dengan ragam ngoko adalah bentuk unggah-ungguh bahasa Jawa yang berintikan leksikon ngoko atau yang menjadi 
unsur inti di dalam ragam ngoko adalah leksikon ngoko bukan leksikon yang lain. Ragam ngoko mempunyai dua bentuk varian yaitu ngoko lugu dan ngoko alus. Yang dimaksud ngoko lugu adalah bentuk unggah-ungguh bahasa Jawa yang semua kosakatanya berbentuk ngoko dan netral. Sedang ngoko alus adalah bentuk unggah-ungguh yang di dalamnya bukan hanya terdiri atas leksikon ngoko dan netral saja melainkan juga terdiri atas leksikon krama inggil, krama andhap, dan krama. Leksikon krama inggil yang muncul di dalam ragam ini biasanya hanya terbatas pada kata benda (nomina), kata kerja (verba) atau kata ganti orang (pronominal). Ragam krama adalah bentuk unggah-ungguh bahasa Jawa yang berintikan leksikon krama, atau yang menjadi unsur inti di dalam ragam krama adalah leksikon krama bukan leksikon yang lain. Ragam krama mempunyai dua bentuk varian yaitu krama lugu dan krama alus. Krama lugu yaitu ragam yang kosakatanya terdiri atas leksikon krama, madya, netral, atau ngoko dan dapat ditambah dengan leksikon krama inggil atau krama andhap. Yang menjadi leksikon inti dalam ragam krama lugu adalah leksikon krama, madya, dan netral. Secara semantik ragam krama lugu dapat didefinisikan sebagai bentuk ragam krama yang kadar kehalusannya rendah. Krama alus adalah bentuk unggah-ungguh bahasa Jawa yang semua kosakatanya terdiri atas leksikon krama dan dapat ditambah dengan leksikon krama inggil atau krama andhap. Secara semantik ragam krama alus dapat didefinisikan sebagai bentuk ragam krama yang kadar kehalusannya tinggi.

Berdasarkan uraian di atas, unggah-ungguh bahasa Jawa dan leksikon pembentuknya dapat dilihat pada bagan 1. Kata yang dicetak miring merupakan leksikon pengisi ragam yang berada di atasnya (Sasangka, 2004: 116-117).

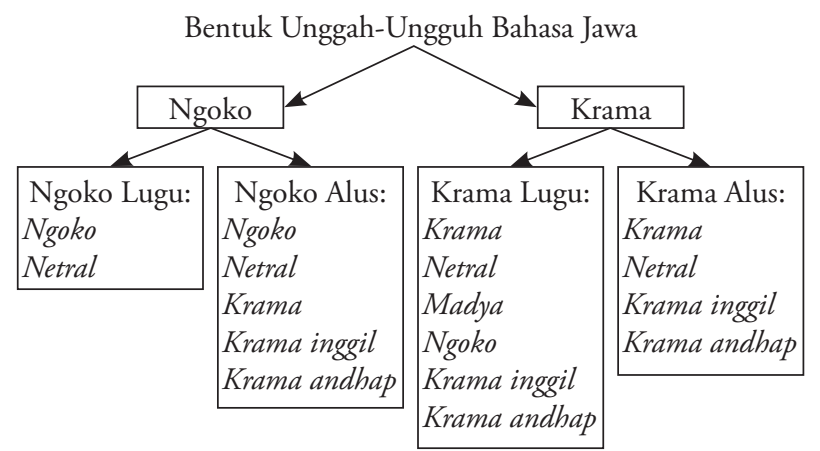

Bagan 1. Unggah-ungguh bahasa Jawa dan leksikon pembentuknya.
Sasangka (2044: 135-154) mengatakan kaidah pemilihan bentuk unggah-ungguh dan kaidah pemilihan bentuk leksikon bahasa Jawa harus mempertimbangkan setting dan participants. Setting atau latar berhubungan erat dengan faktor situasi, sedangkan participants berhubungan erat dengan faktor sosial. Ketika terjadi tuturan, pewicara pasti akan mempertimbangkan faktor sosial orang yang diajak berbicara (mitra wicara) dan faktor situasi pembicaraan itu terjadi. Faktor sosial di antaranya ialah jenis kelamin, umur, hubungan kekeluargaan, jabatan, pendidikan, pendapatan, tempat, waktu, topik, tujuan, dan tingkat keakraban. Kesamaan dan/atau perbedaan faktor sosial peserta ujaran dapat menimbulkan hubungan simetris dan asimetris, akram dan tidak akrab, serta campuran di antara keduanya, yaitu simetris-akrab, simetris-tidak akrab, asimetrisakrab, dan asimetris-tidak akrab. Selain faktor sosial, faktor situasi seperti resmi dan tidak resmi atau formal dan tidak formal ikut pula berperan menentukan bentuk tuturan yang akan digunakan Sasangka (2004: 155) mengatakan bahwa dalam kenyataannya terdapat sejumlah kendala ketika peserta tutur harus memilih jenis leksikon tertentu ketika pembicaraan terjadi terutama pemilihan leksikon krama inggil dan krama andhap. Untuk mengatasinya Sasangka (2004: 156) memberikan rumus bahwa untuk merendahkan diri sendiri demi menghormati mitra wicaranya, pembicara entah $\mathrm{O} 1$ atau $\mathrm{O} 2$ tetap tidak dibenarkan menggunakan bentuk krama inggil untuk dirinya sendiri.

Undha-usuk yang telah dipetakan oleh Sasangka (2004) itulah yang dipakai untuk mengkategorikan ragam bahasa Ki Hadi Sugito. Apakah suatu antawacana 'dialog' yang dituturkan oleh Ki Hadi Sugito termasuk ragam ngoko, madya, atau krama dikategorikan berdasarkan pemikiran Sasangka (2004) tentang ragam bahasa Jawa tersebut.

\section{Ki Hadi Sugito Menggunakan Berbagai Ragam Bahasa Dalam Pergelarannya}

Banyak orang mengatakan bahwa gaya bertutur Ki Hadi Sugito sederhana, komunikatif, segar, dan bahkan lucu. Asumsi ini, dalam kaitannya dengan jenis kode bahasa atau ragam bahasa yang digunakan Ki Hadi Sugito dalam mendongeng, 
menggiring kita untuk segera berkesimpulan ragam bahasa yang dipakai pasti tidak banyak dan tidak yang ndakik-ndakik, rumit-rumit. Namun setelah ditelisik dengan cermat ternyata Ki Hadi Sugito menggunakan ragam bahasa Jawa yang udanegaranya cukup ketat terutama dalam pambagya panakrama jejer sepisan di tiga lakon tersebut. Berdasarkan leksikon yang dipakai dalam mendialogkan tokoh wayang, dapat dikatakan ragam bahasa yang dipakai oleh Ki Hadi Sugito ialah krama inggil, krama alus, basa bagongan, ngoko alus, dan ragam literer. Pemilihan ragam bahasa ini ada hubungannya dengan silsilah, pangkat, dan derajat para tokoh wayang dalam setiap adegan. Silsilah, pangkat, dan derajat selain digunakan dalam pemilihan ragam bahasa, juga digunakan sebagai pedoman dalam menentukan panyebut ('panggilan') antar tokoh (lihat Mudjanattistomo, 1977: 50-66).

Ki Hadi Sugito ketika mendialogkan antar tokoh wayang tetap menerapkan tatakrama basa (Jawa). Dalam menerapkan tatakrama basa ini, seorang dalang dituntut menguasai tentang silsilah wayang, unggah-ungguh, empan papan, dan angon tinon (Mudjanattistomo, dkk., 1977: 49). Tatakrama adalah tata cara berperilaku dan membawakan diri atau bersikap di dalam kehidupan bermasyarakat. Tatakrama basa adalah tata cara bertutur di dalam kehidupan masyarakat (Jawa) dengan mengingat tiga hal yaitu unggah-ungguh, empan papan, dan angon tinon (Mudjanattistomo dkk., 1977: 49-50). Unggah-ungguh merupakan standard ukuran kepatutan berperilaku dan bertutur. Adapun yang menjadi ukuran kepatutan adalah usia, silsilah keluarga, pangkat, dan derajat (lihat Poedjasoedarma, dkk., 1979: 6). Unggahungguh merupakan batasan (pedoman) bagaimana menghargai dan menghormati orang lain dalam kehidupan bermasyarakat (Mudjanattistomo. dkk., 1977:50). Orang (Jawa) yang tahu unggah-ungguh adalah orang (Jawa) yang tahu batasannya (Bhs. Jawa: udanegara).

Ketika berbicara unggah-ungguh kiranya tidak bisa dilepaskan dari empan papan dan angon tinon. Mengapa demikian? Empan papan merupakan ukuran kepatutan berperilaku, bersikap, dan bertutur berdasarkan ruang, sedangkan angon tinon merupakan ukuran kepatutan berperilaku, bersikap, dan bertutur berdasar situasi dan kondisi.
Ruang, situasi dan kondisi akan memberi petunjuk kepada batasan. Dengan demikian unggah-ungguh, empan papan, dan angon tinon merupakan satu kesatuan dalam mewujudkan pemahaman tentang udanegara (batasan).

Di dalam jagat pakeliran segala sesuatu yang tercakup dalam apa yang disebut dengan tatakrama Jawi seperti dikemukakan di atas, merupakan pengetahuan yang diperlukan dalam mendongeng. Artinya seorang dalang yang notabene adalah sang murwèng katha ('pendongeng/tukang cerita') harus menguasai tatakrama Jawi.

Berikut ini petikan teks adegan pasowanan agung di jejer sepisan Lakon Wahyu Widayat yang digunakan untuk menjelaskan ragam bahasa dan penguasaan tatakrama Jawi Ki Hadi Sugito.

Adegan pasowanan agung negara Ngastina di jejer sepisan Lakon Wahyu Widayat melibatkan tokoh Prabu Duryudana, Prabu Baladewa, Pandhita Durna, Patih Sengkuni, dan Bambang Irawan. Dalam adegan pasowanan agung ini terdapat dua komponen yaitu pambagya panakrama ('sambutan tuan rumah terhadap orang-orang yang diundang dalam pertemuan') dan wosing gati ('pokok permasalahan yang dibicarakan'). Dalam adegan ini terjadi dialog antara sang raja dengan para tetua kerajaan, kadang sentana (para ksatria dan para raja vassal), dan punggawa kerajaan (patih, senapati, dsb.).

Pambagya panakrama dalam pasowanan agung memiliki aturan tingkatan menyapa tamu yang hadir. Pertama yang disapa adalah para tetua kerajaan, punggawa kerajaan (perdana menteri), lalu para raja vassal, kemudian kadang sentana atau para ksatria. Dari pengamatan terhadap lakonlakon yang dibawakan dapat dikatakan Ki Hadi Sugito masih memenuhi aturan tersebut.

Dengan melihat leksikon yang dipakai dalam mendialogkan tokoh wayang dalam pasowanan agung di Ngastina, dapat dikatakan ragam bahasa yang dipakai oleh Ki Hadi Sugito ialah krama inggil, krama alus, basa bagongan, ngoko alus, dan ragam literer. Pemilihan ragam bahasa ini ada hubungannya dengan silsilah, pangkat, dan derajat para tokoh wayang dalam adegan tersebut. Selain digunakan dalam pemilihan ragam bahasa, silsilah, pangkat, dan derajat juga digunakan sebagai pedoman dalam menentukan panyebut ('panggilan') antar tokoh (lihat Mudjanattistomo, 1977: 50- 
66). Prabu Duryudana adalah raja Ngastina, Baladewa adalah raja Mandura, Pandhita Durna adalah guru dan penasihat Prabu Duryudana, Patih Sengkuni adalah paman dan juga perdana menteri Prabu Duryudana. Baladewa adalah kakak ipar Duryudana, dilihat dari hubungan isteri-isteri mereka. Bambang Irawan adalah ksatria putra Janaka sehingga dia merupakan keponakan dari Prabu Duryudana dan juga Prabu Baladewa.

Untuk dapat mendialogkan tokoh-tokoh sesuai dengan udanegara, pertama-tama ditelisik silsilah para tokoh. Pengetahuan tentang silsilah tokoh ini dalam jagat pakeliran digunakan sebagai pedoman menentukan ragam bahasa yang dipakai dalam mendialogkan tokoh yang terlibat dalam pasowanan agung tersebut. Silsilah tokoh-tokoh tersebut sudah dapat dipastikan sangat dikuasai oleh Ki Hadi Sugito karena dia, meminjam kata Kayam (2001: 184), adalah dalang turunan yang pendidikannya diperoleh dengan nyantrik. Nyantrik adalah pendidikan informal dengan cara hidup di rumah dalang senior (gurunya) dan mengikuti segala kegiatan mendalang sang guru dalam waktu yang tidak ditentukan. Dengan selalu melihat, memperhatikan dengan cermat, menyimpan dalam ingatan, membuat rumus untuk menghapal, dan nglakoni semua kegiatan dari latihan, diskusi dengan sang guru, persiapan hingga pentas diharapkan selesai nyantrik sang murid sudah dapat menjadi dalang.

Marilah kita telisik hubungan antara Prabu Duryudana dengan Prabu Baladewa. Mereka bersaudara ipar karena isteri-isteri mereka bersaudara. Prabu Duryudana beristerikan Banowati, dan Baladewa beristerikan Erawati (Padmosoekotjo, 1992: 203). Erawati dan Banowati adalah putri Prabu Salya (Padmosoekotjo, 1992: 194). Erawati adalah kakak Banowati. Dengan demikian Baladewa adalah kakak ipar Duryudana. Hubungan kedua tokoh tersebut dapat dilihat dalam gambar 1 .

Bagaimana Ki Hadi Sugito mendialogkan tokoh-tokoh tersebut dapat dilihat dalam petikan teks berikut. Petikan teks dialog antara Prabu Duryudana dan Prabu Baladewa ini diharapkan memudahkan kita memahami hubungan antara silsilah, pangkat, dan derajat dengan penentuan ragam bahasa yang dipakai untuk mendialogkan tokoh wayang tersebut.

Duryudana: "Kaka Prabu, sèwu kalepatan ing- kang rayi nyuwun gunging samodra pangaksami. Sasampunipun prayogi lenggah ri Paduka kula ngaturaken pambagya panakrama, Kaka Prabu." ('Kaka Prabu, sebelumnya mohon maaf karena baru dapat menyambut kedatangan Kaka Prabu. Silakan duduk. Semoga selamat sejahtera terlimpah untukmu Kaka Prabu.')

Baladéwa : "Oh, jagat déwa bathara, nun inggih. Nuwun lajeng kula tampi tangan kekalih, katedha kalingga murda sih panakramanipun Yayi ingkang rumentah dhumateng rakapara. Upami Yayi menika kaleres kadang kula ingkang wredha, ngendikanipun kula cancang pucuking wèni, kasampuraken widhangan dhumawah pangkon, ngimbetana rah daging kayuwanan cahya nurcahya. Kosok wangsulipun Yayi Prabu ingkang kaleres kadang kula taruna, pangandikanipun Yayi kula petelaken wonten dhadha kèndela sami-sami Yayi. Nampi pamujinipun Yayi tuwin pangèstunipun para pinisepuh winantu karaharjan nir sambékala."

('Oh, jagat déwa bathara. Terima kasih banyak atas sambutan dan doa Yayi Prabu. Semoga doamu didengar oleh Yang Maha Kasih. Berkat darimu dan juga berkat para tetua kedatanganku ke sini tidak menemukan aral melintang dan aku selalu dalam keadaan sehat serta dalam lindungan Yang Kuasa.')

(Sugito, Lakon Wahyu Widayat, kaset 1 side A)

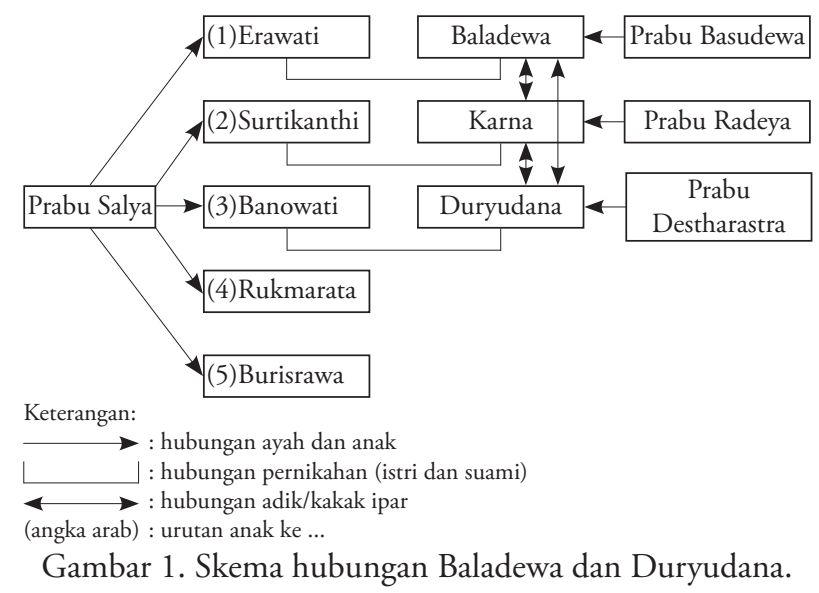


Dari petikan teks tersebut kita memperoleh keterangan tentang sapaan untuk masing-masing tokoh dan ragam bahasa yang dipakai. Duryudana adalah adik ipar Baladewa (lihat gbr.1 skema hubungan Duryudana dan Baladewa) oleh karena itu ia memanggil Kaka Prabu ('Kakanda Raja') kepada Baladewa dan sebaliknya Baladewa memanggilnya Yayi Prabu ('Adinda Raja'). Duryudana adalah raja Ngastina dan Baladewa adalah raja Mandura oleh karena kedudukan merekalah maka dalam pasowanan ('sidang/pertemuan') itu kedua tokoh wayang ini didialogkan dengan menggunakan ragam bahasa krama alus. Gambar 2 memperlihatkan bagaimana hubungan mereka, pangkat dan derajat mereka, serta ragam bahasa yang digunakan dalam adegan pasowanan agung negara Ngastina.

Berikutnya kita lihat hubungan antara Duryudana dan Patih Sengkuni. Hubungan antara Duryudana dan Patih Sengkuni adalah hubungan antara keponakan dan paman. Selain itu hubungan mereka juga hubungan antara raja dan perdana menterinya. Prabu Suwala, kakek Duryudana dari ibunya, memiliki lima orang anak yaitu Prabu Anggendara, Sengkuni, Dewi Anggendari, Sarabasata, dan Gajagsa (Padmasoekatja, 1993: 124). Sengkuni adalah kakak Dewi Gendari. Duryudana adalah anak dari Dewi Gendari. Gambar 3 memperlihatkan hubungan Sengkuni dan Duryudana.

Bagaimana Ki Hadi Sugito mendialogkan tokoh-tokoh tersebut dapat dilihat dalam petikan

Adegan Pasowanan Agung Negara Ngastina

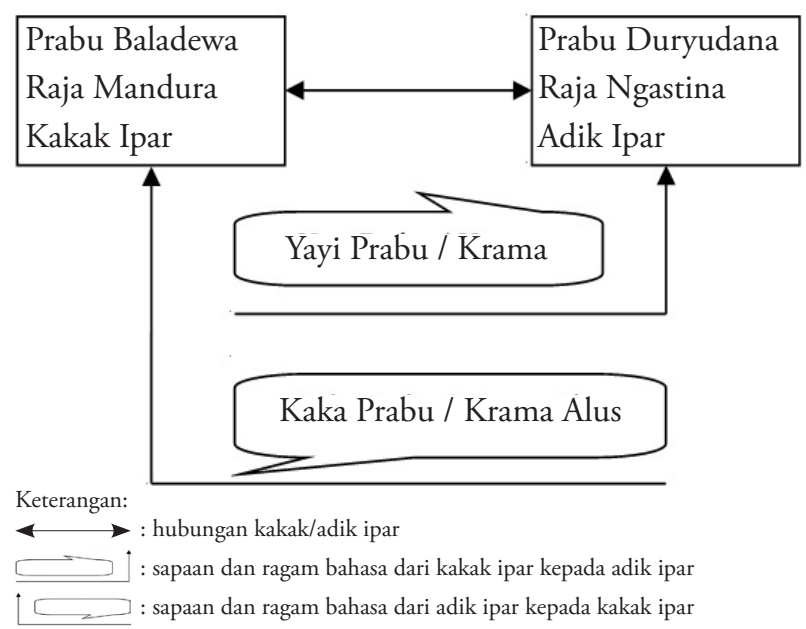

Gambar 2. Skema sapaan dan pemakaian ragam bahasa antara tokoh Baladewa dan Duryudana dalam Pasowanan Agung Negara Ngastina. teks berikut. Petikan teks dialog antara Prabu Duryudana dan Patih Sengkuni ini diharapkan memudahkan kita memahami hubungan antara silsilah, pangkat, dan derajat dengan penentuan ragam bahasa yang dipakai untuk mendialogkan tokoh wayang tersebut.

Duryudana: "Ya èstungkara jagat manik raja déwaku, Paman, Paman Harya mboya ndadosaken galih pekenira manira piji wènten ngersa manira, Paman Sengkuni"

('Ya èstungkara jagat manik raja déwaku, Paman, Paman Harya semoga engkau tidak terkejut kuminta menghadap, Paman Sengkuni.')

Sengkuni : "Gurawalan panampi kula Anak Prabu, sadèrèngipun nampi dhawuh timbalan dalem wonten njawi nggadhahi raos kumarasan. Upami keparenga kula ngibarataken pindha kambengan salamba tinanjer wonten ngalun-alun katempuhing mandra, kumejot kumitir acaruk awor maras. Ewasemanten sasampunipun nampi dhawuh timbalan dalem Anak Prabu tata tentrem raosing manah kula yayah siniram tirta wayu sewindu, kula noknon Anak Prabu."

('Anak Prabu, sebelum kau panggil menghadap, paman merasa sedikit resah. Perasaan paman dapat diibaratkan seperti meniti titian rambut dibelah tujuh. Namun sekarang ketika paman ada di hadapan Anak Prabu, paman merasa lega.')

(Sugito, Lakon Wahyu Widayat, kaset 1 side A)

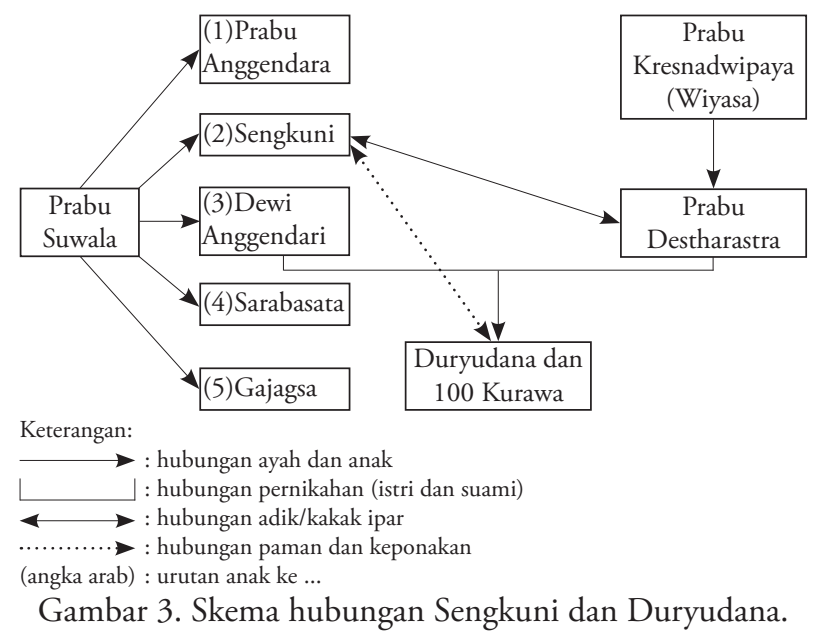


Skema hubungan kekerabatan (lihat gambar 3) dan petikan teks yang melibatkan tokoh Duryudana dan Sengkuni seperti dikemukakan di depan memperlihatkan bagaimana dua tokoh wayang itu saling menyapa/memanggil dan ragam bahasa yang digunakan untuk mendialogkan me reka. Berdasarkan diagram silsilah diketahui Sengkuni adalah paman Duryudana maka ia dipanggil Paman Sengkuni oleh Duryudana dan sebaliknya Sengkuni memanggil Duryudana yang adalah raja Ngastina dengan sapaan Anak Prabu ('Ananda Raja'). Dalam adegan pasowanan agung ini hubung-an mereka adalah antara raja dan patih (perdana menteri) oleh karena itu untuk mendialogkan mereka digunakan ragam krama alus. Gambar 4 memperlihatkan bagaimana hubungan mereka, pangkat dan derajat mereka, serta ragam bahasa yang digunakan dalam adegan pasowanan agung negara Ngastina.

Berikutnya kita lihat hubungan antara Baladewa, Duryudana dan Bambang Irawan. Hubungan antara Baladewa dan Duryudana dengan Bambang Irawan. dapat dilihat dalam gambar 5 .

Berdasarkan gambar 5 kita akan membaca hubungan Baladewa dan Duryudana dengan Bambang Irawan. Agar mudah dibaca hubungan antara Baladewa dengan Irawan akan dibaca dari garis keturunan yang dirunut dari Eyang Buyut. Prabu Basukunthi memiliki lima orang anak yaitu Dewi Sruta, Aryaprabu, Basudewa, Ugrasena, dan Kunthi. Dalam diagram hanya disebutkan dua saja, dengan alasan kepentingan analisis. Basudewa memiliki tiga orang anak yaitu Baladewa, Kresna dan Sumbadra. Sementara itu

Adegan Pasowanan Agung Negara Ngastina

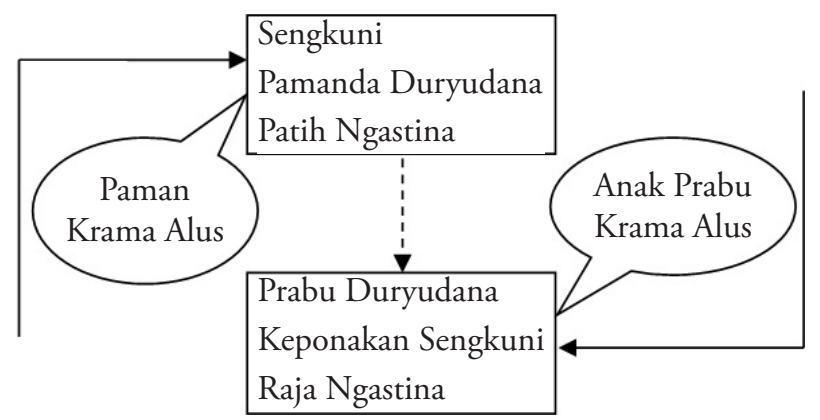

Keterangan:

- - - - - $\rightarrow$ : hubungan paman dan keponakan

: sapaan dan ragam bahasa dari paman kepada keponakan

З : sapaan dan ragam bahasa dari keponakan kepada paman

Gambar 4. Skema sapaan dan pemakaian ragam bahasa antara tokoh Sengkuni dan Duryudana dalam Pasowanan Agung Negara Ngastina. adik bungsu Basudewa yaitu Kunthi memiliki tiga orang putra ialah Yudhistira, Werkodara, dan Janaka (Padmasoekotjo, 1992: 58). Dengan demikian hubungan Baladewa dengan Janaka adalah saudara sepupu. Janaka merupakan adik sepupu dari Baladewa. Dari sinilah kiranya kita dapat mengatakan Baladewa dengan Irawan berhubungan sebagai Uwa/Pakdhe dengan keponakan karena Irawan adalah putra Janaka (dari Dewi Ulupi).

Hubungan Duryudana dengan Irawan sama halnya hubungan Baladewa dengan Irawan. Hubungan mereka juga akan dirunut dari Eyang Buyut. Wiyasa/Kresnadwipayana memiliki tiga orang anak yaitu Dhestarastra, Pandhu, dan Widura (Padmasoekotjo, 1992: 62). Dhestarastra adalah kakak kandung Pandhu. Dhestarastra memiliki putra Duryudana dan 100 orang Kurawa. Sementara Pandhu dengan Kunthi memiliki tiga orang anak yaitu Yudhistira, Werkodara, dan Janaka. Dengan demikian Duryudana dengan Janaka adalah saudara sepupu. Duryudana adalah kakak sepupu Janaka. Oleh karena itu hubungan Duryudana dan Irawan adalah hubungan antara Uwa/Pakdhe dengan keponakan karena Irawan adalah putra Janaka (dari Dewi Ulupi).

Bagaimana Ki Hadi Sugito mendialogkan tokoh-tokoh tersebut dapat dilihat dalam petikan teks berikut. Petikan teks dialog antara Prabu Duryudana dan Prabu Baladewa dengan Bambang Irawan ini diharapkan memudahkan kita memahami hubungan silsilah, pangkat, dan derajat dengan penentuan ragam bahasa yang dipakai untuk mendialogkan tokoh wayang tersebut.

Duryudana: "Ora bakal pangling prunanku Irawan ingkang sowan, padha kanthi raharja?"

('Irawan keponakanku, engkau datang menghadap. Bagaimana kabarmu?')

Irawan : "Kula nuwun inggih nampi pangèstunipun Kanjeng Uwa Prabu winantu karaharjan nir sambékala. Kejawi saking menika sungkeming pangabekti mugi konjuk wonten ngersa dalem Kanjeng Uwa Prabu."

('Berkat doa restu Kanjeng Uwa Prabu, putramu ini dalam keadaan sehat. Kedatanganku menghadapmu pun tidak menemukan suatu halangan. 
Sembah kuhaturkan kepadamu Kanjeng Uwa Prabu.')

Duryudana: "Wus taktampa kanthi bungah, mung pangatutiku gage tampanana."

('Terima kasih, berkatku terimalah.')

Irawan : "Dahat kacancang pucaking wèni sih kadarmanipun Kanjeng Uwa Prabu."

(Terima kasih banyak atas berkatmu Kanjeng Uwa Prabu.')

Baladéwa : "Irawan!"

('Irawan')

Irawan : "Inggih kula Wa."

('Saya Wa')

Baladéwa : "Padha slamet?"

('Bagaimana kabarmu’)

Irawan : "Pangèstunipun Kanjeng Uwa Prabu winantu karaharjan nir sambékala, sungkeming pangabekti konjuk wonten ngandap pada."

('Berkat doa restu Kanjeng Uwa Prabu, putramu ini dalam keadaan baik dan sehat. Sembah kuhaturkan kepadamu Kanjeng Uwa Prabu.')

Baladéwa : "Hiya taktrima."

('Kuterima sembahmu Irawan')

(Sugito, Lakon Wahyu Widayat, kaset 2 side A)

Dari petikan teks tersebut kita memperoleh keterangan tentang sapaan untuk masing-masing tokoh dan ragam bahasa yang dipakai. Duryudana adalah paman/uwa/pakdhe dari Irawan (lihat gambar 5 skema hubungan Duryudana dan Irawan) oleh karena itu ia memanggil nama saja yaitu Irawan kepada Irawan. Demikian juga Baladewa adalah paman/uwa/pakdhe dari Irawan (lihat gbr. 5 skema hubungan Baladewa dan Irawan) oleh karena itu ia memanggil nama saja yaitu Irawan kepada Irawan. Sebagai keponakan dari Duryudana dan Baladewa yang keduanya adalah raja, Irawan memanggil keduanya dengan Kanjeng Uwa Prabu ('Pamanda Raja'). Sebagai orang tua (uwa) dari Irawan maka Duryudana dan Baladewa cukup didialogkan dengan menggunakan ragam ngoko. Sedangkan Irawan kepada kedua orang tuanya (uwa/pakdhe/pamanda) yang juga berkedudukan sebagai raja didialogkan dengan menggunakan ragam krama alus. Gambar 6 memperlihatkan bagaimana hubungan mereka, pangkat dan derajat mereka, serta ragam bahasa yang digunakan dalam adegan pasowanan agung negara Ngastina.

Sekarang kita perhatikan bagaimana Duryudana didialogkan dengan Durna. Pandhita Durna dengan para Kurawa dan Pandhawa memiliki hubungan antara guru dan murid. Selain sebagai guru, di Ngastina Durna berperan sebagai penasihat Prabu Duryudana. Bagaimana Ki Hadi Sugito mendialogkan tokoh-tokoh tersebut dapat dilihat dalam petikan teks berikut. Petikan teks dialog antara Durna dengan Duryudana ini diharapkan memudahkan kita memahami hubungan pangkat dan derajat dengan penentuan ragam bahasa yang dipakai untuk mendialogkan tokoh wayang tersebut.

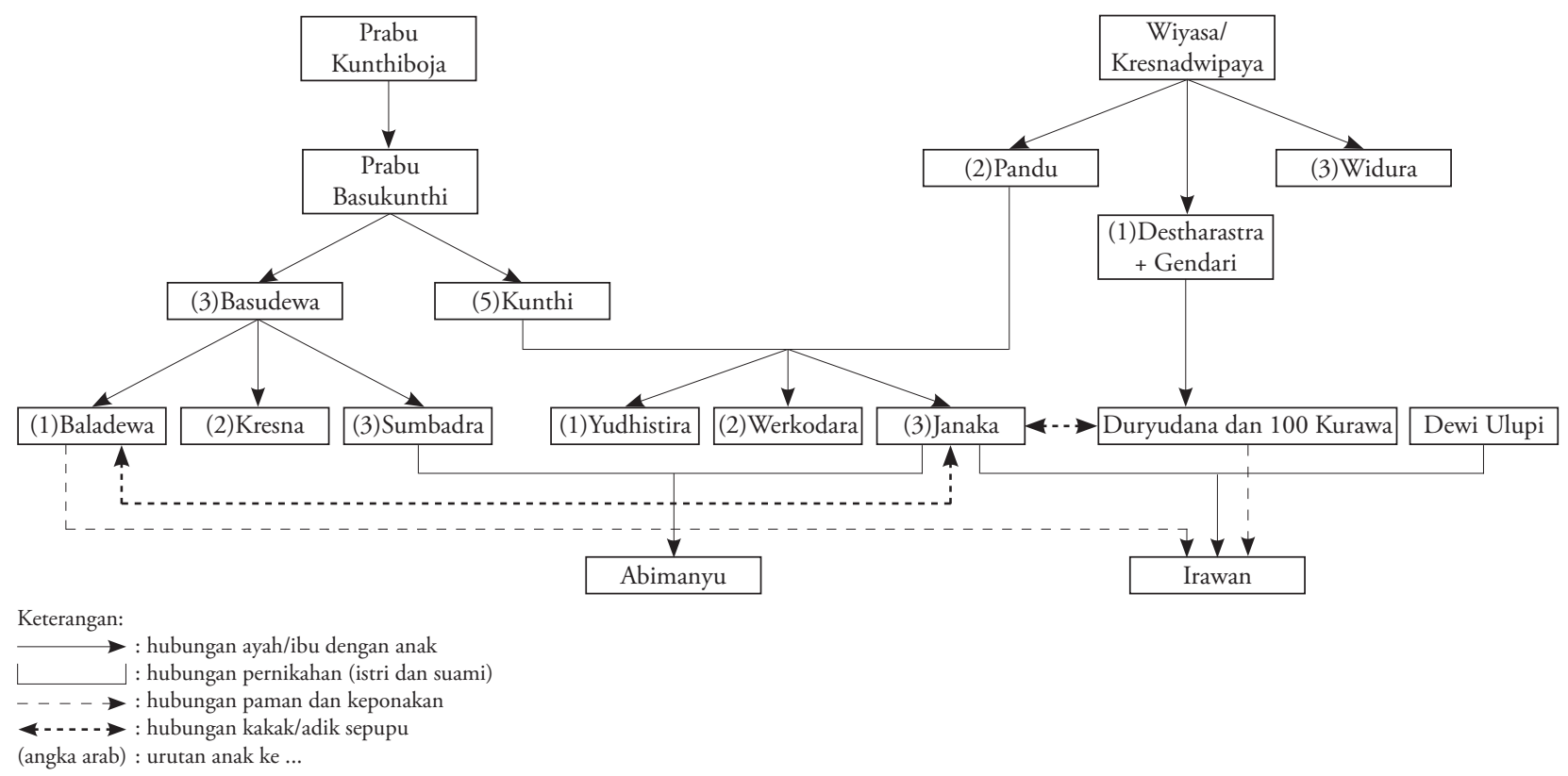

Gambar 5. Skema hubungan Baladewa dan Duryudana dengan Irawan. 
Duryudana: "Kepareng ngaturaken pambagya panakrama saha sungkem pangabekti Bapa Pandhita Durna."

('Bapa Pandhita Durna, selamat datang, semoga kesehatan dan kesejahteraan terlimpah untukmu. Sungkemku terimalah Bapa.')

Durna : "Lolé-lolé gondhog blegudhug monyormonyor. Nuwun lajeng kula tampi ngendikanipun Anak Prabu ingkang sampun kepareng rumentah dhumateng pun bapa, nampi pamujinipun Anak Prabu saha pangèstunipun para déwata winantu karaharjan nir sambékala mboten wonten alangan setunggal menapa. Kejawi saking menika pun bapa ngaturaken pangastuti konjuk wonten ngandhap pada mawantuwantu Anak Prabu, kula noknon non." ('Lolé-lolé gondhog blegudhug monyor-monyor. Terima kasih Anak Prabu atas sambutannya. Berkat doamu dan juga berkat dari dewata bapa tidak menemukan suatu halangan, selamat sejahtera. Anak Prabu terimalah doa dan berkatku.')

Duryudana: "Kula tampi kanthi bingah sih kadarmanipun Bapa Pandhita Durna."

('Dengan penuh sukacita kuterima berkatmu Bapa Pandhita Durna.')

(Sugito, Lakon Wahyu Widayat, kaset 2 side A)

Adegan Pasowanan Agung Negara Ngastina

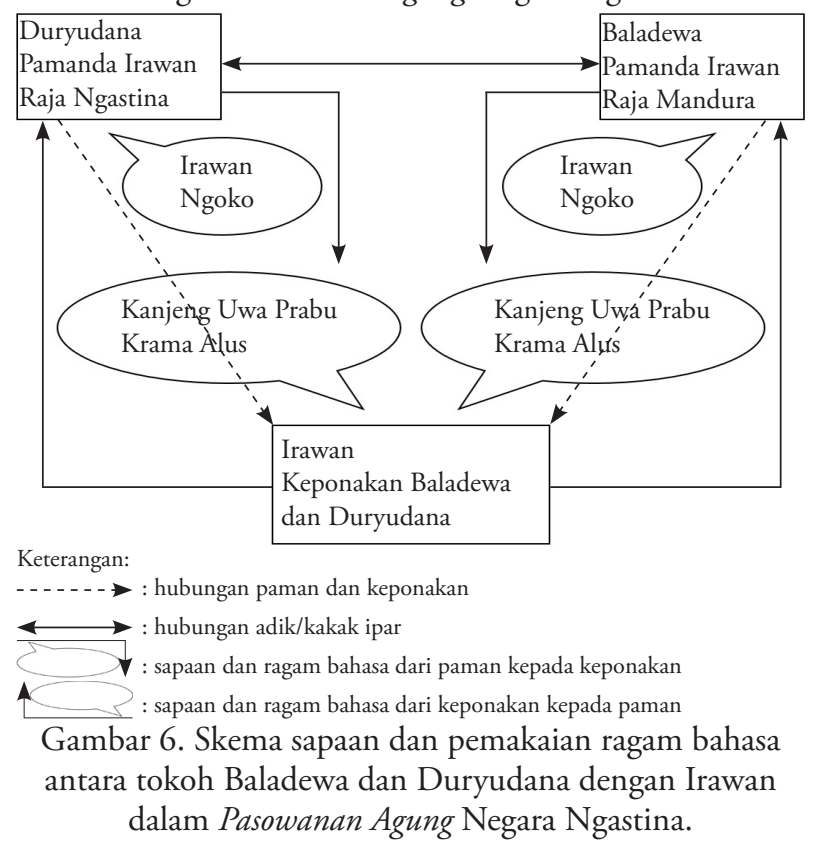

Dari petikan teks tersebut kita memperoleh keterangan tentang sapaan untuk masing-masing tokoh dan ragam bahasa yang dipakai. Duryudana adalah murid dari Pandhita Durna oleh karena itu ia memanggil sang guru dengan sebutan Bapa Pandhita Durna. Sebagai seorang murid dia didialokan dengan menggunakan ragam krama alus kepada Durna. Sedangkan Durna memanggil Duryudana dengan sebutan Anak Prabu dan didialogkan dengan menggunakan ragam krama. Sapaan dan ragam bahasa tersebut didasarkan kepada kedudukan Duryudana sebagai raja Ngastina. Gambar 7 memperlihatkan bagaimana hubungan mereka, pangkat dan derajat mereka, serta ragam bahasa yang digunakan dalam adegan pasowanan agung negara Ngastina.

\section{Ki Hadi Sugito Dalang yang Menguasai Lima Kemampuan Berbahasa}

Seorang dalang pada dasarnya adalah tukang cerita atau pendongeng. Sebagai tukang cerita dia harus pandai menguntai kata dan kalimat. Untaian kalimat yang dihasilkannya adalah untaian kalimat yang estetis yang dalam jagat pedalangan disebut dengan basa padhalangan. Dalam menggelar pertunjukan wayang seorang dalang harus menguntai kalimat candran ('melukiskan segala sesuatu dengan kata dan kalimat yang estetis dan konotatif'), menguntai kalimat narasi yang dalam jagat pedalangan disebut cariyos ('membuat narasi yang estetis adegan di kelir dan adegan imajinatif artinya adegan yang tidak dihadirkan di kelir'),

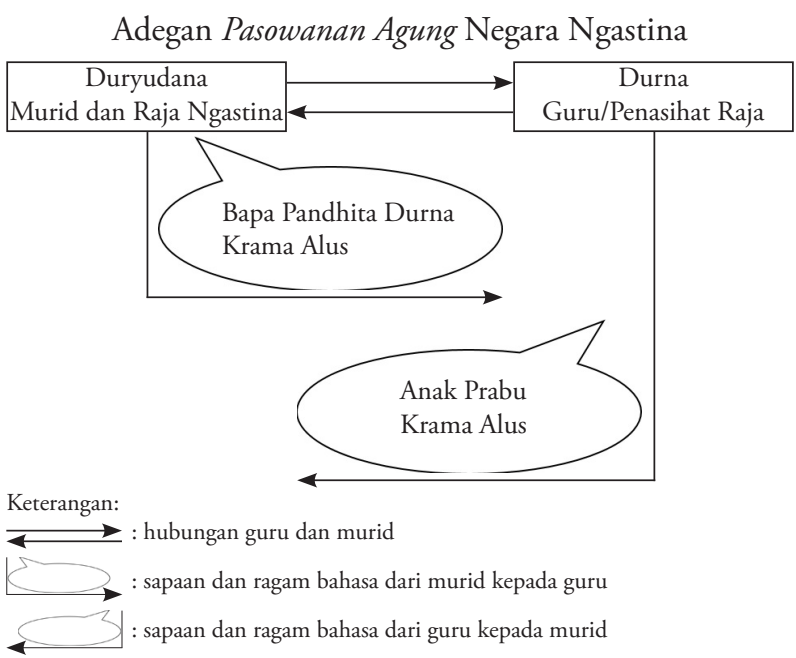

Gambar 7. Skema sapaan dan pemakaian ragam bahasa antara tokoh Duryudana dengan Pandhita Durna dalam Pasowanan Agung Negara Ngastina. 
menguntai kalimat percakapan yang dalam jagat pedalangan disebut ginem ('mendialogkan tokohtokoh di kelir') dan sebagainya. Oleh karena harus ahli dalam menguntai kata dan kalimat maka seorang dalang harus menguasai paling sedikit lima kemampuan yang berhubungan dengan kemampuan berbahasa (Mudjanattistomo, dkk. 1977: 13-14), ialah: (1) marsudi basa artinya seorang dalang harus memiliki kemampuan memproduksi bahasa sesuai dengan kaidah paramasastra Jawa (tata bahasa Jawa), dan sesuai dengan undha-usuk basa Jawa; (2) parama ing basa artinya seorang dalang harus menguasai dan mampu memproduksi serta menerapkan dalam situasi dan kondisi tertentu ragam bahasa pedalangan mulai dari basa ngoko, basa krama, basa krama madya, dan basa bagongan; (3) parama ing kawi artinya seorang dalang harus mengetahui dan dapat menggunakan kata-kata basa kawi yaitu bahasa yang biasa digunakan oleh para kawi / pujangga (ada yang menyebut dengan istilah bahasa Jawa kuna atau kata-kata serapan dari bahasa Sanskerta) dengan tepat; (4) kawiradya artinya seorang dalang harus mampu melukiskan adegan dalam kelir dengan narasi yang imajinatif dan estetis; (5) awicarita artinya seorang dalang harus dapat menggelar cerita secara sistematis sesuai dengan alur dalam struktur pakeliran.

Lima kemampuan berbahasa yang harus melekat pada diri seorang dalang seperti telah diuraikan di atas, ketika kita berbicara tentang Ki Hadi Sugito (alm.) kiranya dapatlah dikatakan bahwa kemampuan berbahasanya tidak perlu diragukan lagi. Ki Hadi Sugito sebagai dalang senior yang hidup dan menghidupi tradisi lisan, hidup pada jaman teknologi manual, dan seorang dalang "turunan" yaitu dalang dengan proses pendidikannya sebagai dalang dilakukan secara tradisional tidak ditempuh melalui sekolah seni formal seperti SMKI atau ISI, begitu Kayam (2001:184) menyebutnya, tentu lima kemampuan berbahasa di atas sudah pasti dikuasai dan diterapkan dalam pergelarannya. Mengapa diasumsikan demikian? Pewarisan secara tradisional dilakukan dengan mengandalkan ingatan dan latihan, itu yang pertama. Kedua, Ki Hadi Sugito hidup di era teknologi dan komunikasi yang belum secanggih dan seterbuka sekarang ini. Dengan demikian dapat dikatakan pendidikan dalang yang diterima belum banyak mendapat pengaruh-pengaruh di luar dunia pendidikan tradisionalnya. Dengan demikian dapatlah dipahami mengapa Kayam (2001: 184) mengatakan bahwa sebagai dalang Ki Hadi Sugito berusaha untuk berpegang teguh pada apa yang dipahaminya sebagai pola pakeliran gaya Yogyakarta.

Petikan teks berikut diambil dari Lakon Bagong Ratu. Petikan ini memperlihatkan penggunaan leksikon-leksikon krama inggil dan ngoko alus. Pemilihan dan pemilahan leksikon dalam petikan ini rupa-rupanya ada kaitannya dengan kemampuan Ki Hadi Sugito dalam hal marsudi basa dan parama ing basa. Unggah-ungguh, empan papan dan angon tinon benar-benar dijaga oleh $\mathrm{Ki}$ Hadi Sugito tentu dengan gayanya. Dalam petikan ini tokoh yang dilibatkan dalam percakapan adalah Puntadéwa dengan Resi Wacanadéwa. Puntadéwa seorang raja yang dalam situasi dan kondisi saat itu berperan sebagai seorang murid dan Resi Wacanadéwa berperan sebagai guru. Hubungan antara murid dan guru inilah yang menentukan pemilihan leksikon ketika harus mendialogkan kedua tokoh tersebut.

Dalam budaya Jawa seorang murid harus menghormati gurunya oleh karena itu dalam mendialogkan Puntadéwa digunakan ragam krama inggil sebagai bentuk penghormatan kepada orang yang lebih tua yang juga gurunya. Sementara dalam mendialogkan Resi Wacanadéwa digunakan ragam ngoko alus. Ragam ngoko alus digunakan dengan pertimbangan Puntadéwa meskipun lebih muda namun ia adalah seorang raja. Berikut petikan dialog antara Puntadéwa dengan Resi Wacanadéwa. Puntadéwa : "Séwu kalepatanipun ingkang putra nyuwun agunging samudra $p a-$ ngaksami Kanjeng Rama Panemban. Dangu lenggah Paduka ingkang putra randhat boten angacarani. Saksampunipun prayogi anggènipun lenggah keparenga putra jengandika ngaturaken pambagé panakrama saha sungkeming pangabekti konjuk ing ngandhap pepada Kanjeng Rama."

("Rama Panemban maafkanlah anakmu ini karena tidak segera menyambut kedatangan Kanjeng Rama Panemban. Sehingga Kanjeng Rama Panemban harus menunggu 
beberapa saat. Terimalah ucapan selamat datang dan salam hormat serta sembah putramu ini Kanjeng Rama.")

Wacanadéwa: "Hong Siwarsana, Yogaku Nggèr Prabu Puntadéwa. Taktampa tangan loro angacarani marang praptané wong atuwamu, sawisé banjur ngaturaké sungkem. Seka gedhening panarimaku, kosok balinélumunturing pangastuti tampanana."

("Hong Siwarsana, muridku Nggèr Prabu Puntadéwa. Salam dan hormatmu kuterima dengan rasa bangga dan terima kasih yang tiada taranya. Oleh karena itu terimalah doa restu dan berkatku.")

(Sugito, Bagong Ratu, kaset I side A)

Petikan yang dibahas tadi adalah petikan yang memperlihatkan hubungan antara murid dan guru. Dalam konteks tersebut antar tokoh dapat dikatakan telah terjalin keakraban namun dalam hubungan tersebut masih harus mengingat kedudukan dan status sosial sang tokoh. Lalu bagaimana Ki Hadi Sugito ketika mendialogkan antar tokoh yang belum saling mengenal dan tidak akrab? Ragam bahasa apakah yang digunakan olehnya. Marilah kita perhatikan petikan berikut. Puntadéwa: "Ki Sanak ingkang nembé prapta, saksampunipun prayogi lenggah, keparenga kula ngaken kadang mudha dhumateng Ki Sanak. Manggih raharja sakpraptanipun Yayi wonten ing sitinggil binaturekena."

("Ki Sanak baru kali ini kita bertemu, namun demikian ijinkanlah anda saya anggap sebagai saudara muda. Yayi, kuucapkan selamat datang, semoga kesejahteraan terlimpah untukmu.")

Bindhirasa: "Wo...jagad dewa bathara inggih. Nun inggih kula tampi tangan kekalih pangandikanipun Sinuwun ingkang rumentah dhumateng jasad kula. Angaturaken genging panuwun Paduka keparengaken kadang mudha dhateng rayi. Nampi pangèstu dalem kados boten kirang setunggal punapa pisowanipun ingkeng rayi dasad kula haunoknon." ("Wo...jagad dewa bathara. Terima kasih banyak Sinuwun atas berkatmu. Berkat restumu, kedatanganku ke negeri ini selamat tiada aral melintang haunoknon.")

Puntadéwa: "Kula nuwun inggih. Sasampunipun prayogi lenggah Paduka punika naléndra saking pundi, sinten sinambating wangi."

("Jika boleh bertanya, dari negeri manakah anda datang dan siapakah nama anda?")

Bindhirasa: "Boten kétang namung samegaring payung paribasanipun kula nyepeng panguwaos piyambak."

("Saya ini seorang raja meskipun negeriku hanya sejengkal.”)

Puntadéwa: "Inggih."

("Raja negeri manakah Yayi?")

Bindhirasa: "Wonten negari Simbar Kemlaka. Kula ingkang sampun kondhang kaonangonang jejuluk Prabu Bindhirasa."

("Raja negeri Simbar Kemlaka. Orang biasa menyebutku Prabu Bindhirasa.")

(Sugito, Bagong Ratu, kaset I side A)

Marilah kita telusuri ginem kedua tokoh tersebut. Berdasarkan kalimat-kalimat dalam ginem dari dua tokoh tersebut dapat dikatakan antara Puntadéwa dan Bindhirasa tidak saling kenal sebelumnya. Dengan demikian hubungan mereka tidak akrab. Kedua tokoh berkedudukan sebagai raja sebuah negara. Dengan memperhatikan kedua hal ini maka Ki Hadi Sugito memilih leksikon krama inggil untuk mendialogkan kedua tokoh.

Selain ragam krama, rupa-rupanya digunakan juga ragam literer untuk mencapai rasa estetis dalam dialog tersebut. Adapun ragam literer yang digunakan berupa paribasan: Boten kétang namung samegaring payung paribasanipun ("meski hanya sejengkal ibaratnya'). Penggunaan ragam literer ini rupa-rupanya dimaksudkan untuk memberi karakter tokoh yang sedikit sombong. Dengan memilih leksikon merendah sebenarnya si pembicara ingin mengatakan sebaliknya. Leksikon samegaring payung ('payung dalam keadaan terbuka') digunakan untuk menunjuk wilayah kekuasaan atau negara. Artinya si tokoh hendak mengatakan bahwa ia adalah seorang raja bukan orang sembarangan.

Masih dalam kaitannya dengan keahlian $\mathrm{Ki}$ Hadi Sugito dalam hal marsudi basa dan parameng 
basa, dalam petikan dialog antara Bethara Narada dan Bagong berikut ini menunjukkan penggunaan ragam krama padewan dan krama madya. Dalam jagat pakeliran, selain leksikon ngoko, krama, bagongan, dikenal juga leksikon padewan. Artinya leksikon-leksikon yang hanya dipakai ketika sang dalang mendialogkan tokoh dewa.

Narada: "Prekencong-prekencong waru dhoyong lhodholo yahok, Bagong."

("Prekencong-prekencong waru dhoyong lhodholo yahok, Bagong.")

Bagong: "Kula ngaturaken pangabekti Pukulun." ("Hamba menghaturkan salam taklim dan sembah Pukulun.")

Narada: "Yoh, ulun trima, ulun tedhak ana ngercapada bakal maringi pitulungan marang jeneng kita."

("Yoh, ulun terima, ulun turun ke ngercapada hendak memberi pertolongan kepada jeneng kita.")

Bagong: "Le ajeng maringi pitulungan kepripun, wong genah awak kula niki pun ancikancik ten pucuk ngeri. Baliya ten Karang Kabolotan diincim-incim, Mang jabut mawon nyawa kula!"

("Mau memberi pertolongan gimana, jelas saya ini sudah seperti telor di ujung tanduk. Kalau pulang ke Karang Kabolotan malah mau dibunuh. Cabut nyawa saya saja!")

Bojo Bagong: "Ho'oh Mas, aku jabutna sisan, dadi mèn wong loro mengko dijabut kabèh Mas. Urip ana kanané, awake dhéwé ora bakal diancam sapadha-padha." ("Ho'oh Mas, nyawaku juga dicabut, jadi kedua-duanya dicabut semua Mas. Hidup di sana, biar kita tidak dikejar-kejar mau dibunuh.”)

Narada: "Wis ora perlu kuwatir. Kita bakal bisa mbongkar marang lakuné angkara murka ingkang manuksma marang praja Ngamarta. Nanging yèn kita bisa nulungi Nini Wara Drupadi ingkeng wektu iki nandhang cintraka ana ing kraton Parangrèjèng."

("Nggak papa, nggak perlu khawatir. Kamulah yang akan membongkar kejahatan yang terjadi di Ngamarta. Asal kamu dapat menolong Nini Wara
Drupadi yang saat ini sedang menderita di kraton Parangrèjèng.")

Bagong: "Njuk kula lé nulungi kepripun?"

("Lalu gimana caraku menolong?")

Narada : "Aja kuwatir ulun paringi pusaka ali-ali musthikaning bumi. Kita kepingin mabur bakal bisa mabur. Kita kepingin ambles bakal bisa ambles. Kita bakal bisa ngrusak marang isining angkara murka, nentremake negara kang ketaman reretu."

("Jangan khawatir, ulun beri pusaka aliali musthikaning bumi. Dengan cincin ini kamu kalau pengin terbang langsung bisa terbang. Ingin masuk bumi langsung bisa masuk. Kamu akan menyingkirkan angkara murka, kamu yang akan membuat ketentraman negara yang sedang dilanda bencana.")

(Sugito, Lakon Bagong Ratu, kaset 7 side B)

\section{Dialog dengan Kalimat-Kalimat Sederhana Digunakan Ki Hadi Sugito untuk Berbagi Pengalaman Hidup (Mbabar Kawrub)}

Ketika mbabar kawruh, Ki Hadi Sugito tidak selalu menggunakan kalimat-kalimat yang serius. Dia sering kali menggunakan rumusan-rumusan penuh humor. Kalimat-kalimat yang tidak ndakikndakik ini rupa-rupanya sengaja dipilih oleh $\mathrm{Ki}$ Hadi Sugito untuk mensintesakan antara rasa jagat pakeliran yang selama ini dianggap sebagai adi luhung dengan keseriusannya, dengan rasa kehidupan orang sehari-hari orang kebanyakan (lihat Sunardi, 2011: 48). Salah satu contohnya dapat kita lihat dalam petikan dialog antara Togog, Bilung dan Prabu Dirgamuka.

Togog : "Bilung!"

("Bilung!")

Bilung : "Apa Kang." (“Apa Kang.”)

Togog : "Kepeneran temen awaké dhéwé, teka dhog gustimu teka mrepegi awaké dhéwé. mBokmenawa ana bejané. Kok wanguné cahyané menter-menter."

("Wah beruntung sekali kita, tuanmu nyamperin, padahal kita baru saja datang. Mungkin sedang kejatuhan durian runtuh. Wajahnya nampak cerah berseriseri.") 
Bilung : "Adat sing wis-wis, wong kuwi angger menter-menter ya ana bejané. Takonana Kang, wis nggawa apa durung."

("Biasanya sih kalau wajah berseri-seri itu sedang bahagia atau mendapatkan apa yang diinginkan. Coba ditanya Kang. Sudah bawa apa belum.")

Togog : “Apa?”

("Apa?")

Bilung : "Bèsèk."

("Bèsèk.")

Togog : "Apa seka kana tekan kéné ming golèk bèsèk."

("Masak dari sana ke sini hanya mau cari besek.")

Bilung : "Sapa ta sing digayuh?"

("Emang apa sih yang diinginkan?")

Togog : "Sekar Wijayakusuma."

("Bunga Wijayakusuma.")

Bilung : "O ya, nyuwuna priksa Kang!"

(“O ya, coba tanya Kang!”)

Togog : "Keparenga kula badhé nyuwun pirsa Kanjeng Déwaji. Saged angsal damel menapa boten?"

("Maaf Kanjeng Déwaji, jika diperkenankan mau tanya nih. Berhasil atau gagal?")

Dirgamuka : "Heh Togog, aku taktakon ikimumpung ora ana liya kejaba mung kowé."

("Heh Togog, mumpung tidak ada siapa-siapa, aku mau nanya.")

Togog : "Nggih."

("Baik, mau nanya apa Kanjeng Dewaji.")

Dirgamuka : "Bojoné Kresna kuwi pira?"

("Istri Kresna berapa?")

Togog : "Lha kersanipun?"

("Kok pertanyaannya itu, ada apa Kanjeng Dewaji?”)

Dirgamuka : "IkimaunyuwunSekarWijayakusuma, ingkang dikersakaké marang Kaka Prabu Ujung Sengara. Sinuwun Dwarawati ngendikani supaya aku ngentèni ana kéné. Aku bakal pamit marang garwa, jer bakal peparing iku aku kudu rembugan marang para garwa."

("Tadi ketika aku minta Bunga Wijayakusuma yang diinginkan Kaka Prabu Ujung Sengara, oleh Sinuwun
Dwarawati aku disuruh menunggu dulu di sini. Katanya akan ngomong dulu sama istri-istrinya.")

Bilung : "Niki pancèn lumrah, jenengé bebrayan, wong bebrayan iku arep ngulungké apa waé marang sapa waé inggih menika kudu rembagan kalih kanca mburi."

("Itu biasa Kanjeng Dewaji. Namanya berumah tangga kalau ingin memberikan sesuatu ya harus ngomong dulu sama istrinya.")

Togog : "Ajeng tetuku napa mawon ya kudu rembagan kanca mburi, ing atasé sing kagungan kersa putri ya kudu matur karo kakungé, menika sampun lumrah yèn cara watak wantuné priyayi tanah Jawi. Rak ya ngono ta Lung?"

("Mau beli apa saja ya harus ngomong dulu sama istri. Seorang istri harus ngomong suaminya kalau mau membeli sesuatu. Ini sudah menjadi adat orang Jawa, begitu ta Lung?”)

Bilung : "Iya. Umpamané onten dhayoh arep nyuwun ngampil, umpama kula nyilih iketé ngaten, mangké sing disilibi ya aku tak tarèn karo bojoku dhisik ngoten. Ampun malih ngrembag punika, saweg mblanjaké mawon yèn kedahipun nggih kakung putri, iki ngko dinggo sapa, iki ngko dinggo nganu ngaten menika."

("Iya. Misalnya ada tamu minjem ikat kepala, pasti saya akan ngomong dulu sama istri saya. Misalnya lagi, kalau mau membelikan sesuatu juga harus jelas antara suami istri. Yang ini untuk siapa, dan yang itu untuk siapa. Begitu Kanjeng Dewaji."

Dirgamuka : "Iya."

("Iya.")

Bilung : "Lan wonten nriku menika kudu nduwèni rasa. Nadyan ta karo seduluré dhéwé nanging rada ngutawatiri ya kudu ditolak ngaten."

("Satu lagi Kanjeng Dewaji. Kalau kirakira kita mencium gelagat tidak baik meski saudara sendiri ya harus berani mengatakan tidak.")

Dirgamuka : "Yèn ngono kudu duwé rasa tegelan."

("Berarti harus tega Lung.") 
Bilung : "Ya tegelan, wonten sing tegelan ngoten menika. Kosok wangsulipun kula nggèné Kang Togog, tur seduluré ngaten umpama mangan ngono ya diétung."

("Ya harus tega. Ini cerita beda lagi Kanjeng Dewaji, saya di tempat Kang Togog makan padahal saudara sendiri, tapi tetap dihitung.")

Togog : "Menawigarwanipun Sinuwun Dwarawati menika sedaya tiga, sekawan ingkang wonten ing dhasaring pertala."

("Istri Sinuwun Dwarawati semuanya tiga, empat dengan yang ada di dasar bumi.")

Dirgamuka : "Sapa waé Gog?"

(“Siapa saja Gog?”)

Togog : "Malah janipun ingkang sepuh piyambak nalika ing dhasaring pertala Dewi Pertiwi. Menika peputra suwargi Prabu Narakasura, ya Setija. Lajeng ingkang dipunsandhing menika tiga, inggih menika Jembawati, Rukmini, Setyaboma."

("Sebenarnya yang pertama itu yang berada di dasar bumi yaitu Dewi Pertiwi. Dengan Dewi Pertiwi memiliki anak Prabu Narakasura, atau Setija yang sudah almarhum. Sedang yang ada di Dwarawati yaitu Jembawati, Rukmini, Setyaboma.")

Dirgamuka : "Parandéné dadi ratu kok garwané nganti pirang-pirang."

("Raja kok istrinya banyak banget.")

Bilung : "Wah nék lumrah mawon, menawi satriya tanah Jawa menika napa malih yèn priksa sing jenengé Janaka niku bojoné wah jagadan."

("Wah itu lumrah saja, ksatria tanah Jawa itu, apalagi Janaka, istrinya itu tak terhitung.")

Sugito, Lakon Ujung Sengara: kaset 2 side B, kaset 3 side A

\section{Perhiasan Bahasa (Bebasan dan Paribasan) Digunakan Ki Hadi Sugito untuk Membangun dan Menajamkan Imajinasi}

Seorang dalang pada dasarnya adalah seorang pujangga. Kalimat-kalimat yang keluar dari mulutnya adalah bahasa susastra. Oleh karena itu dia harus menjadi dalang yang parameng kawi dan kawiradya. Selain itu juga karena pergelaran wayang menekankan pada aspek verbal sebagai sistem komunikasinya (Wahyudi, 2014:1). Dalam hal ini seorang dalang menyampaikan pesan kepada penonton melalui verbal, baik dalam bentuk narasi (meliputi janturan, kandha, dan carita), pocapan, dan suluk.

Seperti telah dikemukakan di depan bahwa Ki Hadi Sugito menguasai lima keahlian dalang dalam kaitannya dengan kemampuan berbahasa. Jika diamati dari jejer hingga tanceb kayon dalam pergelarannya, Ki Hadi Sugito banyak menggunakan bebasan dan paribasan. Penggunaan perhiasan bahasa ini disadari sebagai alat untuk membangun dan menajamkan imajinasi. Berikut petikan-petikan teks yang menggunakan perhiasan bahasa.

Wacanadéwa: "Lho lah sedulur wredhamu anak prabu Bethara Kresna ana ngendi?" ("Lho saudara tuamu anak prabu Bethara Kresna di mana?")

Puntadéwa : "Sampun dangu pangajeng-ajeng kula lan para kadang kados ngentosi kambanging watu item sileming palwa gabus, mekaten."

("Telah lama saya dan para Pandawa menunggu kedatangannya, tetapi seperti menunggu tenggelamnya perahu gabus.")

$$
\text { (Sugito, Bagong Ratu, kaset } 1 \text { side A) }
$$

Bebasan kados ngentosi kambanging watu item sileming palwa gabus digunakan untuk menggambarkan sesuatu yang mustahil bakal terjadi. Kalau pun terjadi itu merupakan keajaiban. Dalam pocapan/ginem di atas diceritakan para Pandawa telah lama menunggu kedatangan Kresna tetapi Kresna tidak datang juga saat itu.

Puntadéwa : "Kanjeng Rama Panemban."

(“Kanjeng Rama Panemban.”)

Wacanadéwa: "Apa Nggèr.”

$$
\text { ("Apa Nggèr.") }
$$

Puntadéwa : "Sasampunipun Dhimas Janaka lorot saking pasowanan, raosing manah kula kados nilar laré wonten sapinggiring jurang, melangmelang sanget."

("Setalah Dhimas Janaka meninggalkan pertemuan, hati saya merasa sangat khawatir") 
Wacanadéwa : "Wis orang usah kawatir mapan iku minangka sarana."

("Sudahlah tidak perlu khawatir, semua itu sebagai sarana”)

(Sugito, Lakon Bagong Ratu, kaset 1 side A)

Petikan teks di atas menceritakan suasana hati Puntadéwa yang dipenuhi kekhawatiran dan juga pertanyaan-pertanyaan apakah Arjuna akan tega membunuh salah satu punakawannya. Untuk menyampaikan suasana hati Puntadéwa Ki Hadi Sugito menggunakan bebasan kados nilar laré wonten sapinggiring jurang ('meninggalkan bayi di bibir jurang').

\section{Pocapan Ki Hadi Sugito Sebagai Sebuah Model}

Setelah menemukan beberapa hal berkaitan dengan ragam bahasa Ki Hadi Sugito seperti dikemukakan di depan, dalam penelitian ini dicoba mereduksi teks Ki Hadi Sugito menjadi teks yang sangat-sangat sederhana dengan catatan tidak menghilangkan kaidah-kaidah basa padhalangan untuk dapat dipraktikkan oleh mahasiswa. Dengan teks yang sangat sederhana ini diharapkan nantinya mahasiswa dapat mayang tanpa membaca teks.

Contoh teks yang dijadikan model adalah teks pocapan pada jejer sepisan Lakon Bagong Ratu bagian pambagya panakrama.

\section{SULUK LAGON SLENDRO PATHET NEM WETAH}

Sri tinon ing paséwakan / busana manéka warna Ong... / sébak puspitèng hudyana / myang panjrah sarwa rukma / renggèng manic narawata ... Ae ana I abra prabanya sumirat / kenyaring téja leliweran / lir kilat sesiring thathit / wimbuh geganda mrik minging / katyuping maruta manda / saparan mangambar kongas Ong ....

\section{SULUK ADA-ADA GIRISA SLENDRO PATHET NEM}

Yata ri sedheng sinéwa Ong... I maha sri darmajaka / prathistèng dhampar kencana / hasri rengganing busana / kinontrang-kontrang sang retna Ong.../ yayah Ywang Darmajaka / suméwa ing Tinjomaya / naléndra rum ngandika ... naléndra rum ngandika I PAMBAGYA PANAKRAMA

Puntadéwa : "Kanjeng Rama Panemban, saksampunipun prayogi anggènipun lenggah keparenga ingkang putra ngaturaken pambagé panakrama saha sungkeming pangabekti konjuk ing ngandhap pepada, Kanjeng Rama."

Wacanadéwa: "Hong Siwarsana, Yogaku Nggèr Prabu Puntadéwa. Taktampa tangan loro. Seka gedhening panarimaku, lumunturing pangastuti tampanana."

Puntadéwa : "Nuwun inggih, kula cancang pucuking wèni, mugi mewahana bawa leksana Rama Panemban."

Wacanadéwa: "Yogaku Nggèr Prabu Puntadéwa iya."

Puntadéwa : "Dhimas Séna lan Dhimas Arjuna aja nganti kadaluwarsa ngaturna pangabekti marang pepundhènmu, Dhimas."

Arjuna : "Ingkangputra Madukarangaturaken pangabekti konjuk wonten ngandhap pada Paduka Kanjeng Rama Panemban."

Werkudara : "Waaaa, Bapa Guruku rawuh, ora liwat aku ngaturaké pangabekti tampanana Bapa Guru batinku."

Wacanadéwa: "Anakku Nggèr Werkudara lan Arjuna taktrima, ora liwat pudya pangastawané pun bapa tampanana."

Werkudara : "Ya taktampa takpundhi ana ing sirahku dadiya jejimat."

Arjuna : "Inggih, kula cancang pucuking weni, mugi ndadosaken rah daging kayuwanan, Kanjeng Rama Panemban."

Kembar : "Nuwun kula kepareng ngaturaken pangabekti konjuk ing ngandhap pada Paduka Panemban."

Wacanadéwa: "Iya, iya Kembar taktrima pangéstuku padha tampanana."

Kembar : "Kula cancang, kula pundhi wonten mustaka."

\section{WOSING GATI}

Puntadéwa : "Kejawi saking punika Rama Panemban, nyuwun lumunturing samudra pangaksami awit kula sakadang sampun kirang trapsila, Kanjeng Rama Panemban kasuwun supados kersa rawuh ing sitinggil binaturetna."

Wacanadéwa: "Hong bawana langgeng. Dhuh Nggèr Putraku Wong Agung Ngamarta 
kaya-kaya ora ana rasa ingkang mesgul malah kagèt ing pamikir déné dina iki pun bapa diparengaké tedhak ing sitinggil binaturetna, bokmanawa ta ana parigawé. Mara ta énggal suka pangerti marang pun bapa paran kang dadi timbuling pasungkawamu."

Puntadéwa : "Kanjeng Rama Panemban, negari Ngamarta ing wekdal samangké kadya nampi sapu dhendhaning jawata ketaman gegeblug ingkang langkung ageng. Kathah para kawula ingkang sami nandhang cintraka, ageng ngantos dumugining layu, Rama Panemban."

Wacanadéwa: "Lho, tha sedulur wredhamu Anak Prabu Bethara Kresna ana ngendi?"

Puntadéwa : "Sampun dangu pangajeng-ajeng kula lan para kadang kados ngentosi kambanging watu item sileming palwa gabus, mekaten."

Wacanadéwa: "Hong bawana langgeng, ya gegambaraning tumitah ana ing ngarcapada contoné kaya déné sesrawunganmu marang Bethara Kresna."

Puntadéwa : "Inggih."

Wacanadéwa: "Srawung iku yèn becik banget ya ora apik yèn adoh banget ya ra becik."

Puntadéwa : "Inggih."

Wacanadéwa: "Upama ta rumaketing rasamu marang Bethara Kresna prasasat kaya déné bumi kang kasorotan Hyang Pratanggapati saben rinané kosok baliné yèn ta ana parigawé lan ana gempiling rasa banjur bisa pisah."

Puntadéwa : "Inggih."

Wacanadéwa: "Bisa uga ana rasa kang kurang prayoga munggwing Bethara Kresna marang putra-putraku ing Ngamarta kabèh."

Puntadéwa : "Mekaten."

Wacanadéwa: "Yèn pancèn kang bapa pinarcaya gawé tentrem, anyingkiraké retuning negara, apa kabèh kadang-kadangmu wis padha nayogyani aku kang minangka dadi wakiling Bethara Kresna."
Puntadéwa : "Kepiyé Dhimas Werkudara?"

Werkudara : "Waa...aku mung percaya mangsa bodhoa kersané Bapa Guruku supaya tentrem negara Ngamarta."

Puntadéwa : "Sedaya para kadang sampun sumungkem wonten ngarsa Paduka Kanjeng Rama Panemban."

Wacanadéwa: "Ya coba mengko taktitipriksané ana rasaku, marang dhawuhing jawata lan ana srana apa kang kudu ditindakaké para putra-putraku Ngamarta."

Puntadéwa : "Inggih."

\section{SULUK LAGON SL. PT. NEM JUGAG}

Hong... lengleng ramyaningkang driya / lir Hywang Candra katawengan / sumuking tyas katuridan / limut kabyataning rujit/ remreming driya manawung I kekuwunging Hyang Wisésa hong...

Wacanadéwa : "Anak Prabu."

Puntadéwa : "Kula nuwun wonten paring pangandika."

Wacanadéwa: "Pancèn abot sranané murih tentreming negara. Apa sekirané Anak Prabu bisa minangkani srana kang kudu takwedharaké iki mengko."

Puntadéwa : "Inggih kula kantun ndhèrèk punapa ingkang dados dhawuh pangandikanipun Kanjeng Rama."

Wacanadéwa: "Iki kepara nyata yèn ta negara Ngamarta ketaman bebendu kang ora gampang tinolak, yèn ta ora bisa ngerti marang sranané."

Puntadéwa : "Inggih."

Wacanadéwa: "Kang kinarya srana tetolaking bebaya wujudé abdi Ngamarta kang kinasih. Yèn ingkang tuwa ya kudu disirnakké. Yèn ingkang enom ya sing enom dhéwé kudu dipatèni."

Puntadéwa : "Punika abdi ingkang pundi Rama Panemban?"

Wacanadéwa: "Wulucumbu ing Madukara iku papat wujudé. Semar Garèng Petruk lan Bagong. Yèn nganggo srana sing tuwa dhéwé ya Semar sing kudu dipatèni. Yèn sing enom dhéwé ya kudu anaké Semar sing ragil sing kudu dipatèni, kanggo tumbaling katentreman ing negara Ngamarta."

Puntadéwa : "Inggih." 
Wacanadéwa : "Sepisan, ingkang angka loro, para putra Ngamarta kabèh ora kena ngucap ngrasani perang Brantayuda."

Puntadéwa : "Kula nuwun inggih."

Wacanadéwa: "Banjur kang angka telu, netepana kuwajibaning naléndra utama, ambeg adil paramarta lega donya lila ing pati."

Puntadéwa : "Inggih mekaten Panemban. Séna!"

Werkudara : "Waa...apa!"

Puntadéwa : "Mengkono kang dadipangandikané Kanjeng Rama Panemban. Paran kang dadi rasamu Dhimas?"

Werkudara : "Yèn aku mung kari manut. Ora Brantayuda waton kabèh para kadang nayogyani aku ya gelem. Nanging anané bab matiné punakawan kang kanggo srana sing kuwajiban punakawan kuwi Janaka. Apa milih Semar apa milih Bagong sing dipatèni."

Puntadéwa : "Kepiyé Dhimas Janaka panemumu?" Janaka : "Menawi Kakang Semar ingkang dipunperjaya kula éman sanget. Awit Kakang Semar punika senajan ta wulucumbu, punika pusakanipun tiyang sanegari. Yèn pancèn wonten srana mekaten keduwung Bagong ingkeng kula suwun dhateng karsanipun Kakang Semar supados kénginga minangka sarana tumbaling praja."

Puntadéwa : "Lila patining punakawan?"

Janaka : "Kula nuwun inggih Kaka Prabu."

Puntadéwa : "Punika Dhimas Janaka sampun ndhèrèk karsanipun Rama Panemban. Lajeng prayoginipun bénjing punapa?"

Wacanadéwa: "Mangsa bodhoa, yèn pancèn kepingin tentrem saiki, ya kudu punakawan mati saiki. Yèn kepingin tentrem mbésuk ya punakawan dipatèni mbesuk."

Puntadéwa : "Dhimas Arjuna kepriyé rasaning pamikirmu? Apa keduga nyirnakaké saiki apa kudu dipenggalih luwih dhisik."

\section{SULUK ADA-ADA}

Mulat marang sang Arjuna / èsmunya kamanungsan ... kamanungsan / Ong... liringé kadi kamantyan
(... ) kongas / ong.. sang mawas risang lengleng abranta / ong...ong...

Janaka : "mBénjing ngentosi punapa sapunika ngentosi punapa. Ingkang rayi badhé bidhal sapunika mejahi panakawan Bagong."

Puntadéwa : "Ora liwat sing prayitna ngati-ati ya Dhi."

Janaka : "Rama Panemban, kula nyuwun pamit."

Wacanadéwa: "Ya takjaluk cilik kowé bisa nggawa kabar Bagong mati, gedhé ngaturaké kunarpané punakawan mau."

Janaka : "Inggih. Kangmas Werkudara, kula nyuwun pamit."

Werkudara : Yoh, mangkat ra nylèwèng-nylèwèng."

Janaka : "Dhateng sendika."

\section{SULUK LAGON SL. PATHET NEM JUGAG}

Hanjrah ingkang sang puspita rum / ong... katyuping samirana mrik / kongas gandaning sekar gadhung mangambar / ong... ong... / raras katon rumeseping driya /I

Puntadéwa : "Kanjeng Rama Panemban."

Wacanadéwa: "Apa Nggèr."

Puntadéwa : "Sasampunipun Dhimas Janaka lorot saking pasowanan raosing manah kula kados nilar laré wonten sapinggiring jurang, melang-melang sanget."

Wacanadéwa: "Wis ora usah kuwatir mapan iku minangka sarana."

Puntadéwa : "Inggih."

Wacanadéwa: "Banjur ingkang pungkasan sawisé aku ditetepaké minangka dadi sesepubing negara Ngamarta, aja nganti aku mau keluputan, takjaluk kanthi rilaning rasamu supaya sedulur wredhamu Anak Prabu Bethara Kresna diaturi rawuh ana negara Ngamarta."

Puntadéwa : "Inggih."

Wacanadéwa: "Sepisan, bakal takjak ngrembug babagan wurunging prang brantayuda. Ingkang angka loro supaya mèlu maringaké tandha tapak asta yèn ta pun bapa kang minangka dadi suh lan tuwa tuwangganing praja Ngamarta." 
Puntadéwa : "Nuwun yèn mekaten kasinggihan. Ingkang putra badhé utusan satunggaling narapraja supados sowan wonten ing negara Dwarawati."

Wacanadéwa: "Mengkono Anak Prabu."

\section{SLK ADA-ADA}

Sidhem jroning pasowanan / wadyagung tanpa sabawa / ong...ong.../ kapraban sang naléndra tama / mangu-mangu kaonengan / lir wuwusing duka cipta / berbudi mandana raras / ong ... ong...

\section{KANDHA}

Dèrèng ngantos paripurna pangandikané nata marang sang mahawiku saha para kadang / kesaru gègèring njaba pyak ngarsa tangkeping wuri / kocapa ingkang manjing wonten ing kraton Ngamarta wus mancat pancaniti nglongok sitinggil binaturetna / utusan saka negara ing Parangrèjèng / utusanira Prabu Kalasereng / raja gagah pideksa myak paséban/ mapanipun ratu tanah sabrang / kurang duga prayoga / ngungalaken dhadha nganglungaken jangganira // SULUK LAGON SL. PATHET NEM JUGAG Gya lumèngsèr / dutaning sang naranata / ong... katekap ing pra wandawa / ong... tan ana kang kuciwa raras / ong... ong...

\section{KATAMUWAN}

Puntadéwa : "Ki Sanak ingkang nembé prapta, saksampunipun prayogi lenggah, manggih raharja sakpraptanipun wonten ing sitinggil binaturetna."

Bindhirasa : "Wo...jagad dewa bathara. Nun inggih kula tampi tangan kekalih pangandikanipun Sinuwun ingkang rumentah dhumateng jasad kula. Angaturaken genging panuwun. Nampi pangèstu dalem, kados boten kirang setunggal punapa pisowan kula, haunoknon."

Puntadéwa : "Kula nuwun inggih. Sasampunipun prayogi lenggah Paduka punika naléndra saking pundi, sinten sinambating wangi."

Bindhirasa : "Boten kétang namung samegaring payung paribasanipun, kula nyepeng panguwaos piyambak."

Puntadéwa : "Inggih."

Bindhirasa : "Wonten negari Simbar Kemlaka. Kula ingkang sampun kondhang kaonang-onang jejuluk Prabu Bindhirasa."
Puntadéwa : "O inggih."

Bindhirasa : "Bindhi, Rasa."

Puntadéwa : "Inggih."

Bindhirasa : "Menapa punika negari Ngamarta kagungan panjenengan dalem Sinuwun Prabu Puntadéwa."

Puntadéwa : "Inggih namung satunggal punika negari Ngamarta. Kula ingkang kepareng nyepeng panguwaos ngatur dhateng para kadang tuwin kawula."

Bindhirasa : "Nun inggih sokur beja sèwu, hoèh ha...ha...ha..., embane ayu-ayu."

Puntadéwa : "Inggih."

Cangik/Limbuk: "Tamuné kok mbebayani temen."

Puntadéwa : "Sasampunipun prayogi lenggah punapa ingkang andadosaken darunaning penggalih, Yayi Prabu tedhak wonten negari Ngamarta."

Bindhirasa : "Sowan kula ingkang sepisan ngaturaken sungkem marang ngarsa dalem. Ingkang kaping kalih, kautus pepundhèn kula sinarawèdi Kaka Prabu Kalasereng naléndra Parang Rèjèng, tinanggenah ngaturaken sungkem marang ngersa dalem Kanjeng Sinuwun Nata Ngamarta"

Puntadéwa : "Kula tampi tangan kekalih kapetelaken ing dhadha kèndela samisami."

Bindhirasa : "Nun inggih, manawi sampun katampi, wosing perlu pisowanan kula, ndikakaken bun-bun enjing njejawah sonten, amit sèwu ingkeng kula lamar sanès kagungan dalem jeplak langak munggwing cèthi srimpi bedhaya sanès, namung sadèrèngipun ampun ngantos ndadosaken sengkeling penggalih."

Puntadéwa : "Boten kados punapa Ki Sanak."

Bindhirasa : "Ingkeng kula lamar boten wonten sanès garwa Ngamarta Dèwi Wara Drupadi, badhe kakersakaken Kaka Prabu, minangka pramèswari kraton Parang Rèjèng. Yèn Paduka Kanjeng Sinuwun marengaken kula aturi ngendika. Kaka Prabu Kalasereng sagah ngonduraken lipet gangsal welas tetumbasan rikala panjenengan dhaup, punapa boten ayem?!" 


\section{Puntadéwa : "Inggih." \\ Bindhirasa : "Kula aturi paring pangandika Kanjeng Sinuwun!"}

\section{SULUK ADA-ADA JUGAG}

Sapengkarna (?) wingis-wingis / kumedut padoning lathi / jaja bang mawinga-winga / ong...ong... I sumungkemé brahmana ong... ong... ong...

Sadéwa : "Takrungok-rungokaké swaramu nebak dhadha, nglangkahi pundhak nyampar talingan. Jenengmu Prabu Bindhirasa?!"

Bindhirasa : "Inggih, panjenengan sinten Radèn?" Sadéwa : "Wragil Ngamarta aku Sadéwa. Apa ya wis umum yèn cara sabrang ingatasé garwa kok dilamar, upama pertimbanganmu banjur dilamar rasaning atimu kepiyé?"

Bindhirasa : "Yèn kula rilèk kok kula."

Sadéwa : "Mangga-mangga, yèn cara Ngamarta kuwi padha karo kowé ngemping lara nggégé pati kepingin njajal kaprawirané para satriya ing Ngamarta. Sanajan ta Kaka Prabu dèrèng paring dhawuh, aku kang bakal suka wangsulan. Takulungaké Kakangmbok Wara Drupadi yèn bisa nglangkahi bangkéné Sadéwa!"

Bindhirasa :Yadhoo tha dalah waha..ha.. ha.. Dedegmu ra sepiraa nantang perkara!"

Sadéwa : :Yèn pancèn kepingin nyoba marang aku metu njaba taksediyani blabaré!"

Bindhirasa : "Babo aja tinggal playu!"

Wacanadéwa : "Nggèr Anak Prabu, tamuné iki mau sangka ngendi?"

Puntadéwa : "Saking negari Parang Rèjèng utusan Prabu Kalasereng Rama."

Wacanadéwa: "Lha mungguh karepé?"

Puntadéwa : "Badhénglamar yayi Wara Drupadi, namung kémawon dèrèng ngantos kula suka katrangan punika wau dhimas Sadéwa lajeng kepara ngayun tanpa nampi dhawuh saking ingkang putra dasad kula, saéngga kedadosan klénta-kléntu Sadéwa damel sayembara perang sesarengan medal njawi dipuntututi kadang kula dhimas Arya Brataséna, mekaten Rama Panemban."
Wacanadéwa: "Kuwi kabèh mau klèru sejatiné. Werkudara nututi ora mèlu campur tangan ya tembungé klèru. Sedéwa wani manggahi pertimbanganmu Wara Drupadi ya klèru."

Puntadéwa : "Inggih. Sapunika kula nyadhong dhawuh wonten ngarsa Paduka kados pundi murih prayoginipun?"

Wacanadéwa: "Mung gumantung ana ngersamu. Upama ta jeneng para manggahi ora mokal, mapan sing jenengé garwa kuwi gempaling rasa katresnan."

Puntadéwa : "Inggih."

Wacanadéwa: "Nanging banjur ilang asmamu. Awit kondhaning ratu Ngamarta kuwi lega donya lila ing pati aja menèh bandha donya, lan aja menèh garwa, nyawané pisan yèn ana kang ngersakaké sumarah munggwing lautan bebasané."

Puntadéwa : "Inggih."

Wacanadéwa: "Yèn netepi marang kuwajibané naléndra utama pertimbanganmu kudu diparingaké, mengkono."

Puntadéwa : "Yèn mekaten prayogikuladhèrèkaken manjing kedhaton mrepegi dhiajeng Wara Drupadi lan kersaa Kanjeng Rama paring seserapan supados dhiajeng Wara Drupadi punika mangké midhèrèk kula paringaken dhumateng utusan sangking Parang Rèjèng."

Wacanadéwa: "Prayoga mengko takkandhanané pertimbanganmu."

Puntadéwa : "Ayo Dhimas Nakula, pun kakang dhèrèkna!"

Nakula : "Nun inggih ngéstokaken dhawuh Kaka Prabu."

\section{Aplikasi Metode Belajar Bahasa Pedalangan dalam Kelas}

Teks hasil penyederhanaan dari petikan teks pakeliran Ki Hadi Sugito yang disajikan di depan kemudian dipraktikkan mahasiswa dengan beberapa tahap. Teks yang dijadikan sebagai model diambil dari Lakon Bagong Ratu versi Ki Hadi Sugito. Tahap pertama mahasiswa diberi penjelasan tentang siapa saja tokoh-tokohnya dan silsilah 
tokoh-tokoh yang terlibat, bagaimana hubungan mereka (silsilah tokoh wayang). Pengetahuan tentang silsilah tokoh wayang yang terlibat dalam adegan digunakan sebagai pedoman menentukan ragam bahasa yang dipakai ketika mendialogkan tokoh tersebut.

Tahap berikutnya mahasiswa diberi penjelasan singkat tentang masalah yang dibicarakan dalam pasowanan agung di jejer sepisan tersebut. Bagaimana masing-masing tokoh memberi tanggapan sehingga mereka dapat mempratikkan greget sahut dengan tepat. Hal ini bertujuan agar mahasiswa dapat mendialogkan tokoh secara logis dan argumentatif.

Tahap selanjutnya mahasiswa membaca teks secara berulang-ulang dengan artikulasi dan retorika yang tepat. Dengan membaca berulangulang diharapkan mereka mengenal dan memahami setiap kata, frasa, dan kalimat. Di samping itu juga dimaksudkan agar kata, frasa, dan kalimat itu tersimpan dalam memori mereka.

Tahap keempat mahasiswa praktik di kelir dengan membaca teks. Di sini mahasiswa

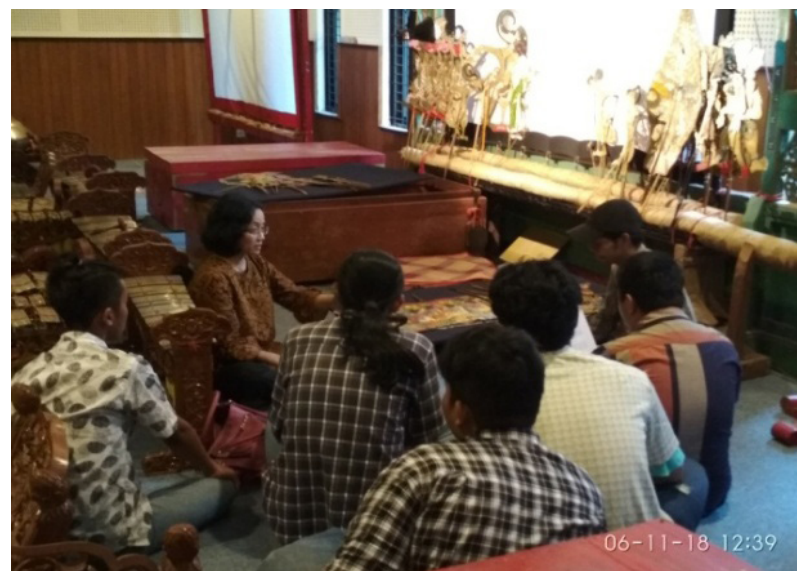

Gambar 8. Guru menjelaskan silsilah tokoh. (Foto: Mikael, 2018)

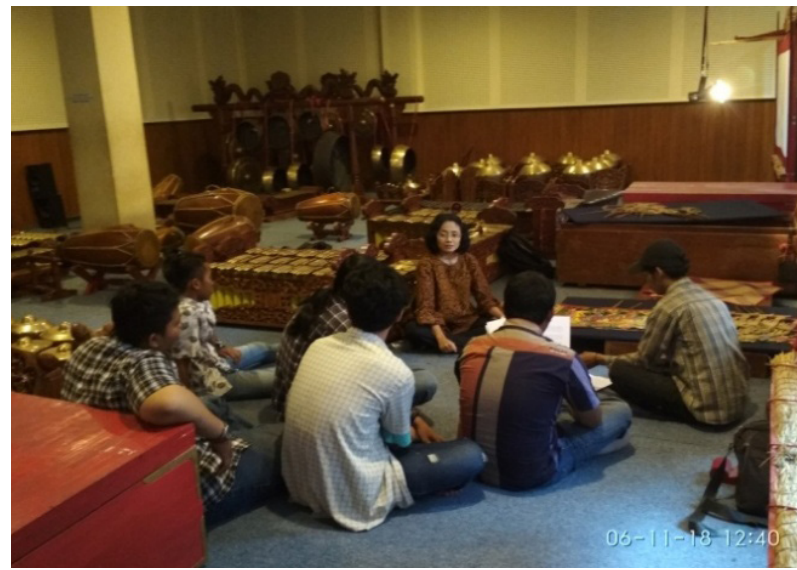

Gambar 9. Guru menjelaskan masalah yang dibicarakan dalam Pasowanan Agung. (Foto: Mikael, 2018) diharapkan menemukan chemistry antara teks yang dibaca dengan tokoh wayang yang didialogkan.

Tahap terakhir mahasiswa praktik di kelir tanpa membaca teks. Di sini mahasiswa mengasah pemahamannya tentang tokoh dan pokok pembicaraan. Di tahap ini mahasiswa diberi kebebasan improvisasi.

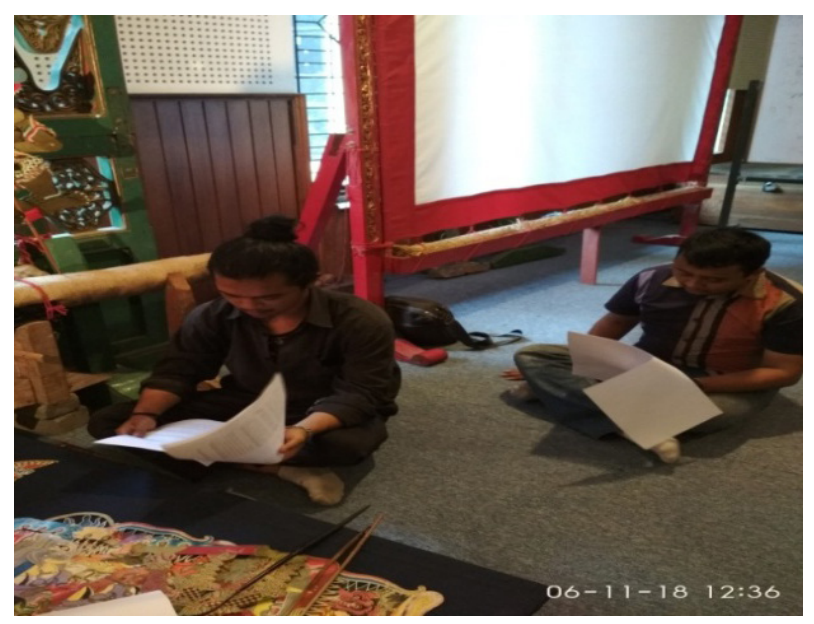

Gambar 10. Mahasiswa membaca teks.

(Foto: Syarif, 2018)

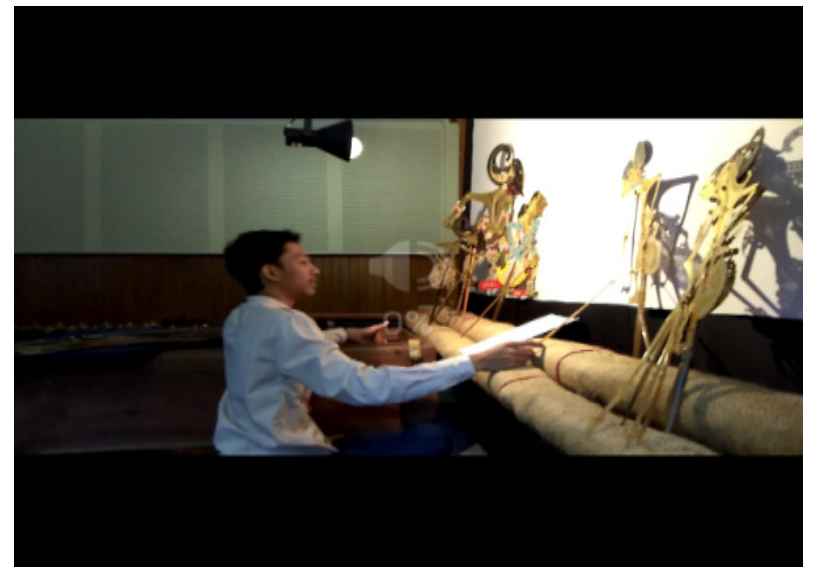

Gambar 11. Mahasiswa di kelir membaca teks. (Foto: Dian, 2018)

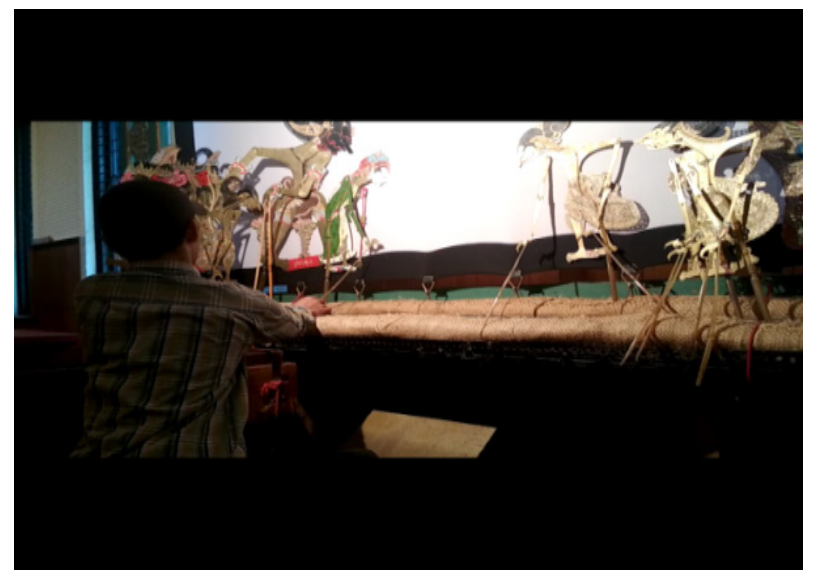

Gambar 11. Mahasiswa di kelir tanpa teks. (Foto: Andre, 2018) 


\section{Penutup}

Mencermati tuturan Ki Hadi Sugito dalam Lakon Bagong Ratu, Ujung Sengara, dan Wahyu Widayat didapatkan beberapa catatan yang menarik. Pertama, dalam menggelar ketiga lakon tersebut Ki Hadi Sugito menggunakan ragam bahasa Jawa yang udanegaranya cukup ketat terutama dalam pambagya panakrama jejer sepisan. Berdasarkan leksikon yang dipakai dalam mendialogkan tokoh wayang, dapat dikatakan ragam bahasa yang dipakai oleh Ki Hadi Sugito ialah krama inggil, krama alus, basa bagongan, ngoko alus, dan ragam literer. Pemilihan ragam bahasa ini ada hubungannya dengan silsilah, pangkat, dan derajat para tokoh wayang dalam setiap adegan. Silsilah, pangkat, dan derajat selain digunakan dalam pemilihan ragam bahasa, juga digunakan sebagai pedoman dalam menentukan panyebut ('panggilan') antar tokoh.

Kedua, Ki Hadi Sugito ketika mendialogkan antar tokoh wayang tetap menerapkan tatakrama basa (Jawa). Dalam menerapkan tatakrama basa ini, seorang dalang dituntut menguasai tentang silsilah wayang, unggah-ungguh, empan papan, dan angon tinon.

Ketiga, sebagai seorang dalang, seorang pendongeng, Ki Hadi Sugito sangat menguasai lima kemampuan berbahasa yang harus dikuasai oleh seorang dalang ialah: (1) marsudi basa artinya seorang dalang harus memiliki kemampuan memproduksi bahasa sesuai dengan kaidah paramasastra Jawa (tata bahasa Jawa), dan sesuai dengan undha-usuk basa Jawa; (2) parama ing basa artinya seorang dalang harus menguasai dan mampu memproduksi serta menerapkan dalam situasi dan kondisi tertentu ragam bahasa pedalangan mulai dari basa ngoko, basa krama, basa krama madya, dan basa bagongan; (3) parama ing kawi artinya seorang dalang harus mengetahui dan dapat menggunakan kata-kata basa kawi yaitu bahasa yang biasa digunakan oleh para kawi / pujangga (ada yang menyebut dengan istilah bahasa Jawa kuna atau kata-kata serapan dari bahasa Sanskerta) dengan tepat; (4) kawiradya artinya seorang dalang harus mampu melukiskan adegan dalam kelir dengan narasi yang imajinatif dan estetis; (5) awicarita artinya seorang dalang harus dapat menggelar cerita secara sistematis sesuai dengan alur dalam struktur pakeliran.
Keempat, ketika mbabar kawruh, Ki Hadi Sugito sering kali menggunakan rumusan-rumusan penuh humor. Kalimat-kalimat yang tidak ndakikndakik ini rupa-rupanya sengaja dipilih oleh $\mathrm{Ki}$ Hadi Sugito untuk mensintesakan antara rasa jagat pakeliran yang selama ini dianggap serius, dengan rasa kehidupan orang sehari-hari orang kebanyakan.

Kelima, Ki Hadi Sugito banyak menggunakan bebasan dan paribasan dari jejer hingga tanceb kayon dalam pergelarannya. Penggunaan perhiasan bahasa ini disadari sebagai alat untuk membangun dan menajamkan imajinasi.

Penelitian tentang Ragam Bahasa Ki Hadi Sugito ini belum tuntas, masih banyak hal-hal yang menarik untuk diteliti di sekitar tuturan Ki Hadi Sugito dalam mempergelarkan wayang. Di antaranya yaitu bagaimana metode Ki Hadi Sugito beralih kode sehingga menghasilkan ragam bahasa yang berhasil mencairkan batas antara kehidupan imajinatif jagat pakeliran dengan kehidupan nyata sehari-hari. Berapa banyak dan berapa dalam pengalaman dan pengetahuan yang dibutuhkan untuk mencapai hal tersebut. Pertanyaan ini belum dilakukan dalam penelitian dengan pertimbangan diperlukan waktu yang cukup lama untuk mencari informan dan narasumber yang berkaitan dengan perjalanan Ki Hadi Sugito kecil hingga menjadi seorang dalang terpopuler di jamannya.

\section{Kepustakaan}

\section{a. Acuan}

Kayam, Umar. 2001. Kelir Tanpa Batas. Yogyakarta: Gama Media.

Kridalaksana, Harimurti, 1993. Kamus Linguistik (Edisi Ketiga). Jakarta: Gramedia Pustaka Utama.

Mudjanattistomo, dkk. 1977. Pedhalangan Ngayogyakarta, Jilid I. Yogyakarta: Yayasan Habirandha.

Padmosoekotjo, S.. 1992. Silsilah Wayang Purwa Mawa Carita Jilid III Cetakan kedua. Surabaya: PT. Citra Jaya Murti. . 1993. Silsilah Wayang Purwa

Mawa Carita Jilid IV Cetakan keempat. Surabaya: PT. Citra Jaya Murti. 
Poedjosoedarmo, dkk. 1979. Tingkat Tutur Bahasa Jawa. Jakarta: Pusat Pembinaan dan Pengembangan Bahasa Departemen Pendidikan dan Kebudayaan.

Sasangka, Sry Satriya Tjatur Wisnu. 2004. Unggah-ungguh Bahasa Jawa. Jakarta: Yayasan Paramalingua.

Sunardi. 2011. "Sisi Satiris Dhagelan Ki Hadi Sugito" dalam Ki Hadi Sugito, Guru Yang Tidak Menggurui. Yogyakarta: BP ISI.

Udreka. 2011. "Jejak Ki Hadi Sugito" dalam Ki Hadi Sugito, Guru Yang Tidak Menggurui. Yogyakarta: BP ISI.
Wahyudi, Aris. 2014. Sambung Rapet dan Greget Sahut, Sebuah Paradigma Dramaturgi Wayang. Yogyakarta: Bagaskara

b. Audio-Visual

Dahlia Record, 1983. Bagong Ratu Ki Hadi Sugito. Kaset rekaman audio.

Dahlia Record, 1983. Ujung Sengara. Ki Hadi Sugito. Kaset rekaman audio.

Dahlia Record, 1983. Wahyu Widayat. Ki Hadi Sugito. Kaset rekaman audio.

Dahlia Record, 1983. Subali Lena Ki Hadi Sugito. Kaset rekaman audio. 